\title{
Psychostimulant-Induced Adaptations in Nucleus Accumbens Glutamatergic Transmission
}

\author{
William J. Wright and Yan Dong \\ Department of Neuroscience, University of Pittsburgh, Pittsburgh, Pennsylvania 15260, USA \\ Correspondence: yandong@pitt.edu
}

Carrying different aspects of emotional and motivational signals, glutamatergic synaptic projections from multiple limbic and paralimbic brain regions converge to the nucleus accumbens (NAc), in which these arousing signals are processed and prioritized for behavioral output. In animal models of drug addiction, some key drug-induced alterations at NAc glutamatergic synapses underlie important cellular and circuit mechanisms that promote subsequent drug taking, seeking, and relapse. With the focus of cocaine, we review changes at NAc glutamatergic synapses that occur after different drug procedures and abstinence durations, and the behavioral impact of these changes.

$\mathrm{D}_{\mathrm{i}}^{\mathrm{r}}$ ug addiction is an acquired, yet pathological, behavioral state that develops following repeated drug use and drug withdrawal. Similar to other adaptive and maladaptive behaviors, drug addiction shares many similarities with natural learning and memory processes. Indeed, the development of drug addiction involves the acquisition/learning of drug use and consolidation of this usage (Everitt and Robbins 2016). Furthermore, addictive behaviors can undergo extinction and reconsolidation, two hallmarks of natural memories (Torregrossa and Taylor 2013). As such, drug addiction is often conceptualized as a pathological form of memory that drives maladaptive behaviors. This has led to the neuroadaptation theory, which postulates that drugs of abuse harness cellular mechanisms that underlie general learning and memory processes to form addiction-related memories (Hyman et al. 2006).

Over the past two decades, a major focus of the addiction research field has been to identify the neural adaptations drugs of abuse induce to alter the function of reward and motivation circuits that drive drug craving, seeking, and relapse. A key node within these circuits is the nucleus accumbens (NAc), which is anatomically positioned as an interface between limbic and motor systems to prioritize and translate motivational arousals into behavioral output (Mogenson et al. 1980). The NAc receives and integrates glutamatergic projections from multiple limbic and paralimbic regions, and transmits the processed information to downstream regions linked to behavioral output through principal medium spiny neurons (MSNs), the

Editors: R. Christopher Pierce, Ellen M. Unterwald, and Paul J. Kenny

Additional Perspectives on Addiction available at www.perspectivesinmedicine.org

Copyright (C) 2020 Cold Spring Harbor Laboratory Press; all rights reserved; doi: 10.1101/cshperspect.a039255

Cite this article as Cold Spring Harb Perspect Med 2020;10:a039255 
W.J. Wright and Y. Dong

projection neurons of the NAc (Sesack and Grace 2010). Although various functional adaptations in NAc MSNs have been detected after exposure to drugs of abuse, drug-induced adaptations in glutamatergic projections to MSNs are particularly critical to the development and maintenance of many addiction-related behaviors. In this review, we provide a summary of the adaptations at glutamatergic synapses of NAc MSNs after exposure to psychostimulants, particularly cocaine, and how these adaptations contribute to addiction-related behaviors.

\section{GLUTAMATERGIC TRANSMISSION IN THE NAC}

A hallmark in vivo pharmacological effect of psychostimulants is the increase in the levels of dopamine within the NAc (Di Chiara and Imperato 1988). This, together with the strong link of the mesolimbic dopamine system to reward processing, positions dopamine as a predominant focus of addiction research for many years (Wise and Rompre 1989; Wise 2004; Volkow et al. 2017). Although dopaminergic signaling in the mesolimbic pathway is clearly important in psychostimulant addiction, NAc dopamine does not appear to be the sole player, and not even an essential player in some cases, in driving relapse after periods of withdrawal from drug use. For example, infusion of dopaminergic antagonists into the NAc of animals previously trained to self-administer cocaine does not affect the subsequent reinstatement of cocaine seeking (Cornish and Kalivas 2000; McFarland and Kalivas 2001). Instead, plenty of evidence establishes a critical role of NAc glutamatergic transmission in drug relapse after withdrawal.

The first wave of evidence comes from studies of locomotor sensitization, a phenomenon wherein repeated exposure to drugs of abuse results in a progressive enhancement of druginduced locomotion. In cocaine-sensitized rats, inhibiting AMPA receptors (AMPARs) in the NAc or lesioning the prefrontal glutamatergic input to the NAc decreases locomotor responding to basal levels, eliminating the sensitized component, whereas infusing AMPA into the NAc in rats with no challenge cocaine injection is sufficient to induce the expression of locomotor sensitization (Pierce et al. 1996, 1998). In the second wave in which cocaine self-administration models are used, inhibiting NAc AMPARs decreases the reinstatement of cocaine seeking after drug withdrawal (Cornish and Kalivas 2000; McFarland and Kalivas 2001), whereas intra-NAc AMPA infusion is sufficient to reinstate cocaine seeking even without external triggers such as drug-associated cues, stress, and priming/challenge injection of cocaine (Cornish and Kalivas 2000). These results demonstrate that NAc glutamatergic signaling is both essential and sufficient in addiction-related behaviors after drug withdrawal, and guide the field toward examining NAc glutamatergic transmission in psychostimulant abuse.

The third wave of studies has started to delineate each component of the NAc glutamatergic circuits in addiction-related behaviors. The NAc receives glutamatergic projections from several other limbic and paralimbic regions, including the prelimbic (PL) and infralimbic (IL) subdivisions of the medial prefrontal cortex (mPFC), the basolateral amygdala (BLA), hippocampus (Hipp), paraventricular thalamus (PVT), and ventral tegmental area (VTA) (Sesack and Grace 2010). These projections are thought to convey different arousal signals to the NAc, where they are integrated for the output of NAc-based behaviors. For example, the BLA projection conveys information related to discrete cues to promote cue-induced reward seeking (Ambroggi et al., 2008), the ventral hippocampus (vHipp) projection conveys spatial information related to context to promote context-induced reward seeking (Ito et al. 2008; Lansink et al. 2009; Trouche et al. 2019), the $\mathrm{mPFC}$ projection is involved in encoding reward-associated discrete cues (Ishikawa et al. 2008), as well as spatial and social information (Murugan et al. 2017). Despite these differential aspects, all these projections promote reward seeking on direct optogenetic activation (Britt et al. 2012; Stuber et al. 2012). In addition, these projections are also critically involved in reinstatement of cocaine seeking after withdrawal (McFarland and Kalivas 2001; McFarland et al. 2003; Di Ciano 2004; Britt et al. 2012; Stefanik 
and Kalivas 2013; Stefanik et al. 2013; Sjulson et al. 2018). It should be noted here that the PL and IL of mPFC have somewhat opposing effects on cocaine seeking, such that activation of the PL promotes, whereas activation of the IL suppresses, cocaine seeking (McFarland and Kalivas 2001; Peters et al. 2008; Stefanik et al. 2013; Cameron et al. 2019). Compared with other projections, the PVT projection to the NAc has been less studied, but emerging evidence suggests its involvement in multiple layers of emotional and motivational arousal (Kirouac 2015). For example, the PVT projection is not only involved in opioid withdrawal-associated aversive behaviors (Zhu et al. 2016), but also the incentive salience underlying the cues that predict rewards (Haight et al. 2015). Furthermore, disruption of the PVT transmission to the NAc compromises the acquisition of cocaine self-administration, but does not affect cue-induced cocaine seeking once the self-administration is acquired (Neumann et al. 2016).

Collectively, projection-specific glutamatergic synaptic transmission regulates NAc-based emotional and motivational responses related to psychostimulant-induced behaviors, especially behaviors associated with relapse after drug withdrawal. In the following sections, we will review psychostimulant-induced adaptations in NAc glutamatergic transmission and the resulting behavioral alterations.

\section{PRESYNAPTIC ADAPTATIONS}

In general, the strength of glutamatergic synapses can be modified through presynaptic (e.g., release probability) and/or postsynaptic mechanisms (e.g., number of receptors). Early studies report that rats behaviorally sensitized to cocaine show significantly increased levels of stimulation-evoked glutamate release (not basal levels) in the NAc (Pierce et al. 1996). Subsequent studies confirm that a similar up-regulation of NAc glutamate is also induced in rats after cocaine self-administration (McFarland et al. 2003). Importantly, such an increase is only detected in rats receiving cocaine through self-administration, but not through yoked infusion, suggesting that this presynaptic adapta- tion is experience-dependent, and related to the learning process of drug taking.

A potential mechanism mediating the increased glutamate levels is cocaine-induced up-regulation of presynaptic release probability, for which early studies provide mixed results. For example, withdrawal from repeated exposure to cocaine increases the frequency of miniature excitatory postsynaptic currents (mEPSCs) in NAc MSNs (Kourrich et al. 2007; Moussawi et al. 2011), a change that can result from either increased presynaptic release or an increase in the number of synapses, but no change in the paired pulse ratio (PPR), an indicator of presynaptic release, is detected in parallel (Kourrich et al. 2007). It is worth noting that the PPR may not be sufficiently sensitive to detect small presynaptic changes, and these studies sampled synapses in a projection-nonspecific manner, although the increase in stimulationevoked glutamate is primarily assessed by stimulating the mPFC projection (McFarland et al. 2003). Recent optogenetic studies with improved projection specificity demonstrate that repeated exposure to cocaine increases the presynaptic release probability $\mathrm{mPFC}$ - and PVTto-NAc synapses (Suska et al. 2013; Neumann et al. 2016) but not BLA- and vHipp-to-NAc synapses (Suska et al. 2013; MacAskill et al. 2014). This presynaptic adaptation at mPFCand PVT-to-NAc synapses occurs as early as after 1 day withdrawal from cocaine self-administration, and persists through long withdrawal periods (e.g., 45 days) (Suska et al. 2013; Neumann et al. 2016).

A potential contributor for this presynaptic adaptation is the dysregulation of glutamate homeostasis (Kalivas 2009). Although the evoked release of glutamate in the NAc is increased after withdrawal from cocaine self-administration, the basal level of glutamate is decreased compared with naive animals (McFarland et al. 2003). The decreased basal levels of glutamate may arise from astrocytes. Cocaine decreases the expression of the glutamate transporter-1 (GLT-1), a major glial transporter in the NAc that moves extracellular glutamate into astrocytes (Reissner et al. 2014). This alteration, in turn, decreases the function of the cysteine/ 
W.J. Wright and Y. Dong

glutamate exchanger that transports glutamate to the extracellular space (Baker et al. 2003). The decrease in extracellular glutamate then leads to a decrease in the basal activation of group II metabotropic glutamate receptors (mGluR2/3) (Moussawi et al. 2011). mGluR2/3 are $\mathrm{G}_{\mathrm{i}}$-coupled receptors primarily located on presynaptic terminals to suppress presynaptic release (Pomierny-Chamioło et al. 2014). As such, the decreased function of these receptors may disinhibit presynaptic terminals after cocaine withdrawal, resulting in increased levels of evoked glutamate release. Consistently, experimentally increasing the activity of mGluR $2 / 3$ normalizes the levels of stimulus-evoked glutamate release in the NAc after cocaine withdrawal (Smith et al. 2016). Importantly, experimental restoration of glutamate homeostasis by restoring basal glutamate levels in the NAc (Baker et al. 2003; Reissner et al. 2014) or increasing mGluR2/3 activities in the NAc (Peters and Kalivas 2006; Smith et al. 2016) attenuates the reinstatement of cocaine seeking after withdrawal.

Taken together, repeated exposure to cocaine and other psychostimulants (RobertsWolfe and Kalivas 2015) increases the release probability of glutamatergic synapses in specific NAc afferents, and this presynaptic adaptation contributes to drug seeking, relapse, and likely other drug-induced behaviors.

\section{POSTSYNAPTIC ADAPTATIONS}

\section{Adaptations in Postsynaptic AMPARs}

After withdrawal from noncontingent exposure (e.g., intraperitoneal [i.p.] injection) to cocaine, AMPAR-mediated glutamatergic synaptic strength in NAc MSNs is persistently increased (Boudreau and Wolf 2005; Kourrich et al. 2007), but this increase can be transiently normalized on reexposure to cocaine (Thomas et al. 2001). Subsequent studies show that this potentiation also occurs after withdrawal from contingent, self-administration of cocaine (Anderson et al. 2008; Conrad et al. 2008; Ortinski et al. 2012; Gipson et al. 2013), albeit with different cellular details between the two conditions (see below). Behaviorally, although com- pelling results link the NAc AMPAR upregulation to the expression of cocaine-induced locomotor sensitization, the time courses of these cellular and behavioral alterations do not perfectly match (Boudreau and Wolf 2005; Pascoli et al. 2013). Specifically, the increase in postsynaptic strength reaches to a significant level only after prolonged withdrawal from the drug (Boudreau et al. 2007; Wolf and Tseng 2012), although locomotor sensitization is expressed right after repeated exposure to cocaine. Rather, the delayed up-regulation of synaptic AMPARs is likely mediated by withdrawal-associated mechanisms rather than an acute effect of cocaine and involved in withdrawal-associated behaviors (see below).

Exposure to cocaine not only quantitatively, but also qualitatively, changes postsynaptic AMPARs in NAc MSNs. In naive or salinetrained rats, the vast majority $(\sim 95 \%)$ of AMPARs in NAc MSNs contain GluA2 subunits and are calcium impermeable (CI-AMPARs) (Conrad et al. 2008). However, following longterm withdrawal from cocaine self-administration, GluA2-lacking AMPARs, which are calcium permeable (CP-AMPARs), are expressed and accumulate (Conrad et al. 2008; Wolf and Tseng 2012; Wang et al. 2018). These cocaine withdrawal-induced CP-AMPARs are thought to primarily be homomeric GluA1containing AMPARs, possibly also with a small portion of GluA1-GluA3 heteromers, as GluA1 subunit is preferentially up-regulated after longterm withdrawal from cocaine (Conrad et al. 2008). In general, accumulation of CP-AMPARs is more reliably detected after more intensive cocaine procedures, such as after prolonged self-administration conditions that result in progressive intensification of cocaine seeking after withdrawal, a behavior phenomenon termed "incubation" of cocaine craving (Grimm et al. 2001) but not after noncontingent cocaine exposure or relatively short self-administration procedures that do not induce incubation (McCutcheon et al. 2011b; Purgianto et al. 2013). However, exceptions do exist for noncontingent procedures in which cue-cocaine association may play a key role (see below) (Pascoli et al. 2014; Terrier et al. 2016; Shukla et al. 2017). 
Nonetheless, pharmacological inhibition (Conrad et al. 2008) or optogenetic removal of NAc CP-AMPARs (Lee et al. 2013; Ma et al. 2014) abolishes incubation of cocaine craving, demonstrating a critical role of CP-AMPARs in promoting the propensity for cocaine relapse after extended periods of withdrawal.

\section{Mechanisms of Psychostimulant-Induced AMPAR Plasticity}

Induction and expression are two relatively independent phases of long-term plasticity at glutamatergic synapses. A heavily studied form of long-term synaptic plasticity is $N$-methyl-D-aspartate receptor (NMDAR)-dependent longterm potentiation (LTP), which is induced by NMDAR activation and expressed, in many cases, through increased function of individual AMPARs or/and an increased number of functional AMPARs (Derkach et al. 2007; Huganir and Nicoll 2013). Similar to other brain regions, NMDAR-dependent LTP can be induced at NAc glutamatergic synapses (Yao et al. 2004; Pascoli et al. 2013). Inhibition of NAc NMDARs during the cocaine procedure prevents cocaineinduced up-regulation of synaptic AMPARs as well as the development of locomotor sensitization (MacAskill et al. 2014), suggestive of cocaine-induced AMPAR regulation as an LTPlike process. In addition to NMDARs, dopamine receptors may also be involved in NAc LTP. Stimulation of dopamine 1 (D1) receptors phosphorylates and promotes synaptic insertion of AMPARs in the NAc (Chao et al. 2002a,b; Mangiavacchi and Wolf 2004). Furthermore, selfstimulation of dopamine neurons is sufficient to up-regulate NAc AMPARs, mimicking the effect of cocaine (Pascoli et al. 2015). Given the substantially increased level of dopamine in the NAc after cocaine administration, it is possible that the dopamine signaling is a molecular bridge for cocaine to up-regulate synaptic AMPARs. This speculation is supported by the observation that the effect of cocaine on AMPARs and the magnitude of cocaine-induced dopamine increases are correlated (Brown et al. 2010). Furthermore, an enhanced VTA dopaminergic signaling to the NAc is es- sential for AMPAR up-regulation in MSNs after repeated exposure to cocaine (Mameli et al. 2009). Thus, activation of NMDARs and dopamine receptors appears to be the first cellular step in the process of cocaine-induced up-regulation of NAc AMPARs.

Intracellular signaling pathways coupled to NMDARs and dopamine receptors may serve as the second step toward cocaine-induced up-regulation of NAc AMPARs. The carboxyl terminus of GluA1 subunit is enriched in modulatory sites (Derkach et al. 2007), among which the Ser831 is the phosphorylation site of calciumcalmodulin kinase II (CaMKII) (Lisman et al. 2012). Activation of synaptic NMDARs induces a calcium influx, which triggers CaMKII-mediated phosphorylation of GluA1, resulting in synaptic targeting and stabilization of GluA1containing AMPA receptors, as well as enhancing their single-channel conduction (Barria et al. 1997; Hayashi et al. 2000; Poncer et al. 2002; Lee et al. 2003; Lu et al. 2010). In addition to GluA1, CaMKII also stabilizes newly inserted synaptic AMPARs through phosphorylation of transmembrane AMPAR regulatory proteins (TARPs) (Tomita et al. 2005; Opazo et al. 2010). Possibly through stabilization of AMPARs and other mechanisms, CaMKII activity also increases the head size of dendritic spines, thus structurally stabilizing the potentiated synapses (Anderson et al. 2008; Robison et al. 2013). These and other molecular processes link the induction to the expression of classic NMDARdependent LTP at glutamatergic synapses (Malenka et al. 1988, 1989; Malinow et al. 1989; Giese et al. 1998). After withdrawal from cocaine, the basal level of active CaMKII in the NAc is increased, corresponding with the increased level of synaptic AMPARs in rats (Boudreau et al. 2009; Ferrario et al. 2011), and likely also in human subjects (Robison et al. 2013). Conversely, inhibition of NAc CaMKII impairs the acquisition of cocaine and amphetamine self-administration as well as the reinstatement of drug seeking after withdrawal (Anderson et al. 2008; Loweth et al. 2013). Thus, CaMKII may be a key signaling component in the induction and expression of cocaine-induced LTP-like up-regulation of synaptic AMPARs in NAc MSNs. 
W.J. Wright and Y. Dong

The cAMP-PKA signaling pathway coupled to $\mathrm{D} 1$ receptors is also implicated in cocaineinduced AMPAR plasticity. Exposure to cocaine, as well as cocaine-predicting cues, triggers a rapid surge of dopamine in the NAc, resulting in activation of D1 receptors and cAMP-PKA signaling pathway (Phillips et al. 2003; Stuber et al. 2005; Surmeier et al. 2007). Inhibition of the NAc D1 receptor-cAMP-PKA signaling pathway compromises the acquisition of cocaine self-administration and other cocaine-associated learning, suggesting the essential role of this pathway (Self et al. 1998; Caine et al. 2007; Anderson et al. 2008; Pisanu et al. 2015). Although the intracellular signaling is typically transient, accumulating evidence suggests that the NAc cAMP-PKA pathway undergo persistent alteration after exposure to cocaine. Specifically, cocaine self-administration leads to an increase in the basal activity of PKA in the NAc, which persists through long periods of withdrawal (Lu et al. 2003), whereas inhibition of NAc PKA results in long-lasting impairment of cocaine seeking (Lynch and Taylor 2005) and consolidation of cocaine memories associated with conditioned place preference (CPP) (Cervo et al. 1997). These long-term behavioral effects may stem from CAMP-PKA-mediated up-regulation of GluA1-containing AMPARs, an up-regulation that has been shown to exist in the NAc (Esteban et al. 2003; Mangiavacchi and Wolf 2004). Interestingly, PKA-mediated trafficking of GluA1-containing AMPARs results in their insertion primarily to extrasynaptic sites, followed by translocation to the synaptic sites on activation of NMDAR-CaMKII signaling (Passafaro et al. 2001; Esteban et al. 2003; Sun et al. 2005; Gao et al. 2006), suggesting a cross talk between the NMDAR-CaMKII and D1cAMP-PKA signaling pathways. This notion is further supported by the observation that the CaMKII activity is required for some of the D1 receptor-mediated effects on NAc AMPARs and cocaine seeking (Anderson et al. 2008).

In addition to the direct effects, the CaMKII and cAMP-PKA signaling may also incorporate other signaling pathways to regulate AMPARs. Exposure to cocaine activates ERK (Boudreau et al. 2007; Ferrario et al. 2011) and CREB
(Mattson et al. 2005), two signaling molecules implicated in transcriptional regulation of postsynaptic adaptations of NAc glutamatergic synapses after exposure to cocaine (Brown et al. 2011; Pascoli et al. 2013). The ERK and CREB signaling pathways, together with other signaling pathways, form a complex transcriptional and translational network involved in psychostimulant-induced cellular adaptations, but the content is beyond the scope of the current manuscript. Interested readers may find several indepth reviews on this topic (Chao and Nestler 2004; Carlezon et al. 2005; Lu et al. 2006; Girault et al. 2007; Dong and Nestler 2014).

Although the adaptations discussed above primarily pertain to Hebbian-like plasticity, another important form of plasticity, namely homeostatic plasticity, should not be ignored. Indeed, it is thought that most molecular and cellular changes after exposure to drugs of abuse are homeostatic responses (Kalivas 2005). Homeostatic plasticity is the adjustment of synaptic strength or membrane excitability up or down to maintain a stable functional output of neurons in response to "unexpected" changes (Turrigiano 2008; Davis 2013). Homeostatic mechanisms regulating synaptic strength and membrane excitability often interact with each other to achieve an overall stability. In the NAc, changes in synaptic input induce changes in the membrane excitability of MSNs, and vice versa, which is termed "synapse-membrane homeostatic cross talk" (SMHC) (Ishikawa et al. 2009; Wang et al. 2018). Through SMHC, an increase or decrease in synaptic input lead to decreases or increases in membrane excitability, respectively. The SMHC "sensors” for synaptic strength are GluN2B-containing NMDARs, which convey a signal of synaptic strength through the coupled CaMKII signaling to regulate the membrane excitability (Wang et al. 2018). Following cocaine self-administration, synaptic levels of AMPARs are minimally altered initially (see above), but synaptic GluN2B-containing NMDARs are up-regulated (Huang et al. 2009), which generates a false signal of an increase in the glutamatergic synaptic strength and triggers the first round of synapseto-membrane SMHC to decrease the membrane 
excitability through up-regulation of SK2-type calcium-activated potassium channels (Wang et al. 2018). The decreased membrane excitability, and ultimately spiking output, triggers a second membrane-to-synapse SMHC, promoting synaptic accumulation of CP-AMPARs after long-term withdrawal (Wang et al. 2018). Importantly, disrupting SMHC during cocaine self-administration, thus preventing subsequent CP-AMPAR accumulation, disrupts incubation of cocaine craving after long-term withdrawal (Wang et al. 2018). These results provide an example that homeostatic dysregulation is induced by drug experience to participate in establishing pathophysiological changes at NAc glutamatergic synapses.

In many brain regions, early-stage expression of NMDAR-dependent LTP is partially mediated by synaptic insertion of CP-AMPARs, which are replaced by CI-AMPARs during the late stage (Shi et al. 2001; Plant et al. 2006; Guire et al. 2008; Morita et al. 2013; Park et al. 2016). The prolonged expression of synaptic CP-AMPARs in the NAc after withdrawal from cocaine self-administration is partially mediated by dysregulated mechanisms underlying CP-AMPAR trafficking. After withdrawal from cocaine selfadministration, eukaryotic elongation factor 2 (eEF2) and eukaryotic initiation factor $2 \alpha$ (eIF2 $\alpha$ ) are dephosphorylated, effects that promote protein translation (Werner et al. 2018), and the eEF2- and eIF $2 \alpha$-dependent protein translation is required for maintaining high levels of CP-AMPARs in NAc MSNs during withdrawal from cocaine (Scheyer et al. 2014). However, the effects of cocaine on protein translation appear to be confined to GluA1 without affecting the overall protein translation (Stefanik et al. 2018). In addition to the potentially increased expression, synaptic maintenance of CP-AMPARs is also altered after withdrawal from cocaine. In saline-trained animals, the tonic mGluR1 signaling promotes CP-AMPAR internalization, contributing to low levels of $\mathrm{CP}$ AMPARs at glutamatergic synapses on NAc MSNs (Loweth et al. 2018). In animals after withdrawal from cocaine, experimental activation of mGluR1 reverses the accumulation of synaptic CP-AMPARs (McCutcheon et al. 2011a; Loweth et al. 2014). However, the basal level of NAc mGluR1 is decreased after withdrawal from cocaine, which, together with NMDAR and other signaling, may lead to insufficient removal, and thus accumulation, of CP-AMPARs (Loweth et al. 2014; Stefanik et al. 2018).

\section{Cell-Type and Pathway Specificity}

The results discussed above were obtained by broad sampling of NAc synapses, which presumably arise from most NAc afferents. With optogenetics distinguishing different NAc afferents, recent studies reveal that after withdrawal from noncontingent exposure to cocaine, glutamatergic synapses in the mPFC (Pascoli et al. 2013), BLA (MacAskill et al. 2014), vHipp (Britt et al. 2012), and PVT (Joffe and Grueter 2016) projections to NAc MSNs are all potentiated, albeit with some degree of discrepancy after different cocaine procedures. Subsequent studies show a similar cross-projection potentiation after withdrawal from cocaine self-administration, but with unique features in each projection. Specifically, IL-to-NAc synapses are potentiated partially through up-regulation of CP-AMPARs, although PL-to-NAc synapses are potentiated primarily through up-regulation of CI-AMPARs (Pascoli et al. 2013, 2014; Ma et al. 2014). Similar to the IL projection, potentiation of BLA-to-NAc synapses is associated with synaptic incorporation of CP-AMPARs (Lee et al. 2013; Ma et al. 2016; Terrier et al. 2016). In contrast, potentiation of neither vHipp-to-NAc synapses nor PVT-to-NAc synapses is associated with CP-AMPARs (Pascoli et al. 2014; Neumann et al. 2016). Thus, although most examined glutamatergic projections to the NAc are potentiated after withdrawal from cocaine, the potentiation in each projection is likely achieved through different mechanisms.

In addition to the projection specificity, cocaine-induced synaptic adaptation is also differentially induced in different MSN subpopulations in the NAc, namely MSNs that express high levels of dopamine D1 receptors (D1MSNs) versus MSNs that express high levels of dopamine D2 receptors (D2-MSNs) (Gerfen et al. 1990). D1- and D2-MSNs have overlap- 
W.J. Wright and Y. Dong

ping, but also distinct projection patterns, and are thus thought to be involved in different aspects of motivated behaviors (Bocklisch et al. 2013; Kupchik et al. 2015; O'Connor et al. 2015; Creed et al. 2016). This notion is supported by observations that selective manipulation of NAc D1-MSNs versus D2-MSNs with optogenetics or chemogenetics often results in different or, on many occasions, opposing effects on reward/drug-elicited behaviors, with D1-MSNs promoting, whereas D2-MSNs suppressing these behaviors (Lobo et al. 2010; Bock et al. 2013; Cheng et al. 2016). However, the concept of behavioral separation between NAc D1- versus D2-MSNs should not be taken in its extreme term. In vivo recordings detect that both D1- and D2-MSNs are activated in reward-elicited behaviors, although differing in activation pattern (Calipari et al. 2016). Furthermore, D2MSNs are recruited to establish cocaine CPP (Sjulson et al. 2018). Moreover, through different downstream projections, NAc D1-MSNs are simultaneously involved in two seemingly opposite behaviors, drug reinstatement and extinction (Gibson et al. 2018). Thus, although NAc D1and D2-MSNs are capable of "opposing" each other, their activation is highly coordinated for successful accomplishment of naturally occurring behaviors.

After most commonly used drug procedures, cocaine-induced potentiation of glutamatergic synapses primarily occurs in D1-MSNs (Dobi et al. 2011; Bock et al. 2013; Pascoli et al. 2013, 2014), which is in concert to the role of D1 receptors in regulating AMPAR trafficking discussed above. However, synaptic strengthening can also be induced in D2-MSNs after robust cocaine self-administration procedures (Terrier et al. 2016). Given that experimentally strengthening glutamatergic synaptic inputs to D2MSNs dampens cocaine-motivated behaviors (Bock et al. 2013), it is tempting to speculate that cocaine-induced synaptic strengthening in D2-MSNs functions as an endogenous mechanism to circumvent the development of drug addiction. Nonetheless, despite certain inconsistencies, most studies detect a reliable synaptic potentiation in the BLA, mPFC, vHipp, and PVT projections to NAc D1-MSNs after with- drawal from noncontingent cocaine procedures (MacAskill et al. 2014; Pascoli et al. 2014; Joffe and Grueter 2016). After prolonged withdrawal from cocaine self-administration, the potentiation of mPFC-to-D1-MSN synapses (Pascoli et al. 2014; Terrier et al. 2016), and also likely BLA-to-D1-MSN synapses (Lee et al. 2013), involves synaptic incorporation of CP-AMPARs. Compared with D1-MSNs, results related to D2MSNs are mixed, with no changes (Pascoli et al. 2014), potential weakening (Kim et al. 2011), or strengthening (Bock et al. 2013; Terrier et al. 2016) all observed.

Cocaine-induced adaptations in different projections to the NAc differentially contribute to cocaine-associated behaviors. After withdrawal from cocaine, optogenetic induction of long-term depression (LTD) that selectively reverses cocaine-induced potentiation of $\mathrm{mPFC}$ to-NAc synapses compromises the expression of locomotor sensitization and cue-induced cocaine seeking (Pascoli et al. 2013, 2014; Ma et al. 2014). However, projections from the PL and IL subdivisions of the MPFC have differential effects, with depotentiation of cocaine-potentiated PL-to-NAc synapses reducing cue-induced cocaine seeking, whereas depotentiation of IL-to-NAc synapses enhancing this behavior ( $\mathrm{Ma}$ et al. 2014). For BLA-to-NAc synapses, reversing or preventing cocaine-induced potentiation also compromises locomotor sensitization and cue-induced cocaine seeking after drug withdrawal (Lee et al. 2013; MacAskill et al. 2014). For vHipp-to-NAc synapses, reversing cocaine-induced potentiation similarly decreases cue-induced cocaine seeking (Pascoli et al. 2014). For PVT-to-NAc synapses, however, disrupting their transmission does not affect cue-induced cocaine seeking after drug withdrawal (Neumann et al. 2016), raising the possibility that, rather than positive reinforcement, drug-induced adaptations at PVTto-NAc synapses are preferentially involved in negative affective states, as demonstrated in a study of opioids (Zhu et al. 2016).

\section{Silent Synapses and Synaptogenesis}

Experience-dependent synaptic plasticity typically occurs as a strengthening and weakening 
of preexisting synapses. However, under certain conditions, experience-dependent plasticity is also associated with generation of new synapses (Holtmaat and Svoboda 2009). Generation of new synaptic connections between neurons may create new pathways or patterns of information flow, which can be critical in forming memories of novel experiences that have never been confronted. This is particularly relevant to the development of drug addiction, during which new, multidimensional associative memories are established in drug-naive subjects.

During the brain development, newly generated immature glutamatergic synapses often only contain NMDARs, whereas AMPARs are either absent or highly labile, thus AMPARsilent synapses or, simply, silent synapses (Kerchner and Nicoll 2008). After development, synaptogenesis becomes less active and levels of silent synapses decline substantially (Durand et al. 1996; Petralia et al. 1999). However, synaptogenesis continues in adult brains for metabolic turnover as well as experience-induced synaptic remodeling (Maletic-Savatic et al. 1999; Holtmaat et al. 2006; Xu et al. 2009; Yang et al. 2009). Newly generated synapses in the adult brain are thought to be thin or filopodia-like, consistent with nascent silent synapses during development (Maletic-Savatic et al. 1999; Matsuzaki et al. 2001; Holtmaat et al. 2006; Knott et al. 2006; Fu et al. 2012). These nascent, immature synapses then gradually enlarge (Knott et al. 2006), corresponding to the functional maturation via AMPAR incorporation (Matsuzaki et al. 2004). Some of these experience-generated synapses persist over the lifetime of a memory and are critical for the behavioral expression of these memories (Yang et al. 2009; Attardo et al. 2015; Cichon and Gan 2015; Hayashi-Takagi et al. 2015). These results lead to a compelling possibility that experiencegenerated synapses encode specific memory traces of these experiences.

Exposure to cocaine and other psychostimulants increases the density of dendritic spines in the NAc, suggesting a synaptogenesis process (Robinson and Kolb 1999; Robinson et al. 2001; Russo et al. 2010). In concert, electrophysiological recordings reveal that either noncon- tingent- or self-administration of cocaine increases the level of silent synapses in NAc MSNs (Huang et al. 2009; Wright et al. 2019). Cocaine-generated silent synapses show several features that are consistent with nascent, immature synapses: (1) they are enriched in GluN2Bcontaining NMDARs (Huang et al. 2009; Brown et al. 2011), a hallmark of nascent glutamatergic synapses (Monyer et al. 1994; Kirson and Yaari 1996; Tovar and Westbrook 1999); (2) blocking AMPAR internalization does not prevent cocaine-induced generation of silent synapses (Graziane et al. 2016); and (3) cocaine-induced increase in silent synapses is tightly correlated to a selective increase in the densities of thin and filopodia-like spines (Graziane et al. 2016). As such, these silent synapses may represent a distinct set of new synapses that are specifically generated for cocaine experience.

During withdrawal from cocaine, newly generated NAc silent synapses gradually mature by recruiting AMPARs, with a maturation process lasting 7-10 days (Huang et al. 2009; Lee et al. 2013; Shukla et al. 2017). If generation of silent synapses establishes new, cocaine-specific circuit patterns, maturation may consolidate these patterns and enhance the corresponding behavioral outputs. Consistent with this notion, experimentally resilencing the already matured silent synapses or preventing the maturation process decreases the magnitude of cue-induced cocaine seeking and place preference (Lee et al. 2013; Shukla et al. 2017; Wright et al. 2019). In theory, high levels of cocaine seeking require intact cocaine-associated memories, successful reactivation of these memories, and mechanisms that support the expression of cocaine seeking. Recent results show that resilencing cocaine-generated synapses before memory reactivation effectively decreases subsequent cocaine seeking, but during cocaine seeking once it is triggered, cocaine-generated synapses are in an AMPAR-silent state (Wright et al. 2019). These results tie cocaine-generated silent synapses to the storage or reactivation, instead of the expression of cocaine memories.

Cocaine-induced generation of silent synapses is detected in all three glutamatergic projections to the NAc that have been tested thus 
W.J. Wright and Y. Dong

far, including projections from the BLA (Lee et al. 2013), both the IL and PL of the mPFC (Ma et al. 2014), and PVT (Neumann et al. 2016). However, how the synapses mature differs among these projections. In the BLA and IL projections, cocaine-generated silent synapses mature after drug withdrawal by recruiting CP-AMPARs (Lee et al. 2013; Ma et al. 2014), although in the PL and PVT projections, silent synapses mature by recruiting CI-AMPARs (Ma et al. 2014; Neumann et al. 2016). Thus, through silent synapse generation and maturation, these and possibly other glutamatergic projections to the NAc are remodeled, potentially resulting in projection-specific behavioral consequences. Indeed, after withdrawal from cocaine self-administration and maturation of silent synapses, experimentally resilencing silent synapses selectively in the BLA or PL projection attenuates cue-induced cocaine seeking and thus incubation of cocaine craving (Lee et al. 2013; Ma et al. 2014), suggesting that silent synapse-mediated remodeling of the BLA and PL promotes drug relapse. In contrast, resilencing silent synapses in the IL-to-NAc projection enhances cue-induced cocaine seeking (Ma et al. 2014), suggesting an antirelapse function of this remodeling. The behavioral consequence of silent synapsemediated remodeling of the PVT-to-NAc projection has not been examined, but it has been shown that disrupting the entire projection does not affect cue-induced cocaine seeking after drug withdrawal (Neumann et al. 2016), a result that, to some extent, excludes the involvement of PVT-to-NAc projection in cocaine seeking.

The cell-type specificity of cocaine-induced generation of silent synapses remains underexplored. A recent study, however, observed that, after noncontingent exposure to cocaine, silent synapses are primarily generated on D1-MSNs (Graziane et al. 2016). After long-term withdrawal and maturation of silent synapses, the ratio of glutamatergic synaptic strength in D1-MSNs over D2-MSNs is increased, suggesting that, through generation and maturation of silent synapses selective on D1-MSNs, the balance of the NAc output is shifted in favor of D1MSNs. Because noncontingent exposure and self-administration can induce different synap- tic adaptations (Wolf 2016), it will be important to determine whether the D1-MSN-selective generation of silent synapses holds true after cocaine self-administration.

The molecular mechanisms underlying synaptogenesis during development and adulthood are complex and still insufficiently understood (Waites et al. 2005; Südhof 2018). In the context of cocaine-induced generation of silent synapses and potential synaptogenesis, several mechanisms are potentially involved (Russo et al. 2010; Dong and Nestler 2014), among which are CREB- and $\triangle$ FosB-mediated transcriptional mechanisms. CREB is a transcriptional factor downstream from the cAMP-PKA pathway, which is rapidly activated in the NAc after exposure to cocaine, resulting in multidimensional behavioral consequences (Carlezon et al. 1998, 2005; Terwilliger et al. 1991; Barrot et al. 2002). Experimental expression of an active form of CREB in hippocampal neurons induces silent synapses and spinogenesis (Murphy and Segal 1997; Marie et al. 2005), which may result from CREB-mediated transcription of synaptogenic proteins (McClung and Nestler 2003). In the NAc, mimicking cocaine-induced up-regulation of CREB activity increases the density of dendritic spines and triggers the generation of silent synapses in cocaine-naive animals, although preventing CREB activation prevents generation of silent synapses and spinogenesis in cocaine-trained animals (Brown et al. 2011). These results suggest that cocaine-induced activation of CREB is one of the initial molecular processes leading to subsequent cellular changes in the NAc, such as generation of silent synapses and synaptogenesis. Similar to CREB, $\triangle$ FosB is also involved in transcriptional regulation of many synaptogenic proteins (McClung and Nestler 2003). Repeated exposure to cocaine induces repeated production of $\Delta \mathrm{FosB}$, which, because of its resistance to degradation, gradually accumulates and persists throughout the withdrawal periods (Hope et al. 1994; DamezWerno et al. 2012; Lobo et al. 2013; Robison et al. 2013). Overexpression of $\Delta$ FosB selectively increases the density of immature spines in NAc D1-MSNs in cocaine-naive mice, but not D2-MSNs, suggesting D1-MSNs-selective gen- 
eration of silent synapses (Grueter et al. 2013; Robison et al. 2013). Thus, CREB and $\triangle$ FosB potentially regulate cocaine-induced generation of NAc silent synapses in a similar manner. Indeed, the acute genomic effects of CREB and $\Delta$ FosB are strikingly similar in the NAc (McClung and Nestler 2003), leading to an important question of how the CREB and $\triangle \mathrm{FosB}$ transcriptional signaling pathways interact and coordinate to promote synaptogenesis and silent synapses generation after exposure to cocaine.

A prominent endogenous activator of CREB is the cAMP-PKA signaling pathway, which is coupled to D1 receptors and thus may result in D1-MSN-specific effects of CREB activation. This scenario provides a molecular mechanism for D1-MSN-selective generation of silent synapses after certain cocaine procedures (Graziane et al. 2016). Associated with early genes, $\Delta$ FosB can be induced by a variety of signaling pathways, among which a recent study shows that both CREB and serum response factor (SRF) are required for the cocaine-induced increase in $\triangle$ FosB in the NAc (Vialou et al. 2012), suggesting CREB as an upstream component to $\Delta$ FosB. Further supporting the upstream status of CREB, after certain cocaine procedures, $\triangle \mathrm{FosB}$ and spinogenesis are selectively induced in NAc D1-MSNs (Lobo et al. 2013). It is important to note that other signaling pathways, such as the CaMKIV and TrkB-MAPK signaling, also regulate CREB activities (Carlezon et al. 2005; Muschamp and Carlezon 2013). Thus, through BDNF and NMDA receptors, CREB may also be activated in non-D1-MSNs after some cocaine procedures.

On activation of CREB, $\triangle \mathrm{FosB}$, and other synaptogenic signaling, the next critical step for cocaine-induced generation of silent synapses is the up-regulation of GluN2B-containing NMDARs. GluN2B-containing NMDARs are up-regulated by CREB and $\triangle$ FosB signaling in the NAc (Brown et al. 2011; Grueter et al. 2013), and have been critically implicated in synaptogenesis (Tovar and Westbrook 1999; Nakayama et al. 2005; Gambrill and Barria 2011). Repeated exposure to cocaine up-regulates GluN2B-containing NMDARs in the $\mathrm{NAc}$, with a large portion residing at newly generated silent synapses, whereas preventing CREB activation prevents cocaine-induced upregulation of GluN2B-containing NMDARs (Huang et al. 2009; Brown et al. 2011).

Following initial cocaine-induced upregulation, GluN2B-containing NMDARs are gradually replaced by non-GluN2B NMDAR subtypes during drug withdrawal (Wright et al. 2019), indicative of synaptic maturation and stabilization (Barria and Malinow 2002, 2005; Adesnik et al. 2008; Gray et al. 2011; Matta et al. 2011). This NMDAR subtype switch may involve $\triangle F$ FosB signaling, which is persistently active after exposure to cocaine (Chao and Nestler 2004). Specifically, cyclin-dependent kinase-5 (Cdk5), a downstream gene of $\Delta$ FosB signaling, is triggered to be expressed at high levels in NAc MSNs after exposure to cocaine (Bibb et al. 2001). High levels of Cdk5 promote phosphorylation GluN2B subunits at the S1116 site, a posttraslantional regulation that allows internalization of GluN2B-containing NMDARs for replacement and synapse maturation (Norrholm et al. 2003; Plattner et al. 2014). Another player that may participate in stabilizing cocaine-generated synapses is PSD-95, a synaptic scaffold protein regulating the maturation and stabilization of glutamatergic synapses (El-Husseini et al. 2000; Ehrlich et al. 2007; Hanse et al. 2013; Favaro et al. 2018). In mouse cortical neurons, genetic deletion or knockdown of PSD-95 prevents neonatal silent synapses from maturation (Favaro et al. 2018). In NAc MSNs, knockdown of PSD-95 prevents maturation of cocaine-generated silent synapses (Shukla et al. 2017). Both the GluN2B- and PSD-95-associated synaptic maturation and stabilization mechanisms are not unique to cocaine, but rather "generic" for most CNS glutamatergic synapses. What is unique for maturation of cocaine-generated silent synapses is the CP-AMPAR insertion. In previous sections, we have discussed potential mechanisms related to the cross-board up-regulation of synaptic CPAMPARs. It remains to be examined whether these discussed mechanisms or, rather, some cocaine-specific mechanisms mediate the $\mathrm{CP}$ AMPAR insertion to cocaine-generated silent synapses, and whether these newly inserted 
W.J. Wright and Y. Dong

CP-AMPARs are stable or subject to further modification.

\section{Transient Synaptic Plasticity}

Thus far, we have discussed long-term adaptations at NAc glutamatergic synapses that contribute to drug-induced behaviors. Several lines of recent studies show that transient plasticity may also play an important role in expression of drug-seeking and, likely, the dynamics of cocaine-associated memories.

One of the most studied forms of such transient plasticity is induced in animals after extinction from cocaine self-administration, after which cocaine seeking diminishes to low levels. At this time point, reexposure to the cues previously associated with cocaine self-administration reinstates strong cocaine seeking. This cue reexposure transiently increases the strength (measured by AMPAR/NMDAR ratio) of glutamatergic synaptic transmission to NAc MSNs, and this potentiation lasts $\sim 2$ hours (Gipson et al. 2013), whereas preventing this transient potentiation compromises cue-induced reinstatement of cocaine seeking (Smith et al. 2014, 2016). In the cocaine-seeking test, operant responses typically do not result in cocaine infusion (thus, seeking), but if cocaine infusion occurs, this transient potentiation is rapidly reversed (Spencer et al. 2017). In these cue reexposure tests, cocaine-trained animals are exposed to not only the cocaine-associated cues that may elicit cocaine memories, but also cues/contexts associated with the extinction procedure that may prevent cocaine seeking. Subsequent studies reveal that the transient potentiation is induced by both cocaine- and extinction-associated cues, but preferentially expressed in D1-MSNs versus D2-MSNs, respectively (Roberts-Wolfe et al. 2018, 2019). Thus, through NAc D1-MSNs versus D2MSNs, this transient potentiation may promote both cocaine seeking and refraining simultaneously, with the final behavioral readout determined by the balance of these two processes.

Mechanisms underlying this transient potentiation have begun to be unveiled, involving a multistep regulation of glutamatergic signaling in the NAc. Specifically, this transient potentiation is dependent on glutamate release from the mPFC projection, such that inhibiting the mPFC-to-NAc projection abolishes this potentiation (Gipson et al. 2013; Stefanik et al. 2016). Released glutamate is thought to subsequently activate mGluR5 on a subset of local inhibitory interneurons that express neuronal nitric oxide synthase (nNOS) (Smith et al. 2016). Activation of mGluR5, in turn, triggers the release of nitric oxide (NO) from these interneurons, which activates matrix metalloproteinase 9 (MMP-9), eventually leading to postsynaptic potentiation of glutamatergic synapses on MSNs (Smith et al. 2014, 2016). The signaling mechanisms downstream from MMP activation underlying the transient postsynaptic potentiation remain to be determined, but may involve cell-adhesion molecules such as integrin (Wiggins et al. 2011; Huntley 2012; Mulholland et al. 2016).

In contrast to cue-induced potentiation after extinction from cocaine self-administration, reexposure to cocaine after withdrawal from noncontingent cocaine administration triggers a transient depotentiation of NAc glutamatergic synapses (Boudreau et al. 2007; Kourrich et al. 2007), and this depotentiation contributes to cocaine-induced reinstatement of CPP (Benneyworth et al. 2019). Furthermore, this cocaine-induced depotentiation appears to occur specifically at synapses in the IL projection, a projection that suppresses cocaine-seeking behaviors (Peters et al. 2008; Ma et al. 2014). Thus, this depotentiation may contribute to cocaine seeking by removing the suppressive break.

Although the above-described transient plasticity directly influences ongoing behaviors, other forms of transient plasticity may function to regulate cocaine-associated memories. Similar to other memories, consolidated cocaine-associated memories can be transiently destabilized on cue-induced memory reactivation, and then reconsolidated approximately 6 hours later (Tronson and Taylor 2007; Torregrossa and Taylor 2013). During this 6-hour destabilization window, cocaine-associated memories become susceptible to disruption. To explore the synaptic underpinnings, a recent study examines the functional state of cocaine- 
generated silent synapses (Wright et al. 2019). On reexposure to cocaine-associated cues after withdrawal from cocaine self-administration, cocaine-generated silent synapses become transiently resilenced via internalization of CP-AMPARs, and then mature again by rerecruiting CP-AMPARs 6 hours later, defining the destabilization and reconsolidation of cocaine-associated memories. Furthermore, preventing the rematuration of cocaine-generated synapses during the destabilization window prevents memory reconsolidation and decreases subsequent cue-induced cocaine seeking, a behavioral readout of cue-associative cocaine memories. These results depict a synaptic mechanism dictating the dynamic states of cocaineassociated memories.

\section{CONCLUDING REMARKS}

We have attempted to provide a relatively thorough review of adaptive changes at NAc glutamatergic synapses that have clear implications in addiction-related behaviors. These findings position NAc glutamatergic transmission as a key cellular target through which cocaine and other psychostimulants reshape motivated behaviors. Although we are excited by these important findings, we would also like to raise two conceptual considerations for future studies. First, these findings represent an enormous number of drug-induced adaptations, each characterized from a reductionistic point of view. However, drug addiction is a behavioral consequence resulting from complex neuroadaptations crossing multiple domains. It might be the time to meta-analyze these findings from a holistic point of view for higher levels of understanding of the brain mechanisms underlying drug addiction. Second, most of these findings are obtained in tissues prepared from drug-trained animals. As such, the changes in synaptic compositions or structures may accurately predict how the functional capacity of these synapses is altered (e.g., a six-gear car upgraded to a nine-gear car), but how these synapses are operating during the behavior (e.g., whether the car is actually running in gear two, four, six, or nine) remains to be determined. It is our wishful thinking that some of the results or viewpoints included in this manuscript may provide a stepping stone for future studies to address these and other challenging but exciting questions.

\section{ACKNOWLEDGMENTS}

The authors' work was partially supported by National Institutes of Health Grants DA043940 to W.J.W. and Grants DA023206, DA047861, DA040620, and DA04538 to Y.D.

\section{REFERENCES}

Adesnik H, Li G, During MJ, Pleasure SJ, Nicoll RA. 2008. NMDA receptors inhibit synapse unsilencing during brain development. Proc Natl Acad Sci 105: 5597-5602. doi:10.1073/pnas.0800946105

Ambroggi F, Ishikawa A, Fields HL, Nicola SM. 2008. Basolateral amygdala neurons facilitate reward-seeking behavior by exciting nucleus accumbens neurons. Neuron 59: 648-661. doi:10.1016/j.neuron.2008.07.004

Anderson SM, Famous KR, Sadri-Vakili G, Kumaresan V, Schmidt HD, Bass CE, Terwilliger EF, Cha JHJ, Pierce RC 2008. CaMKII: a biochemical bridge linking accumbens dopamine and glutamate systems in cocaine seeking. Nat Neurosci 11: 344-353. doi:10.1038/nn2054

Attardo A, Fitzgerald JE, Schnitzer MJ. 2015. Impermanence of dendritic spines in live adult CA1 hippocampus. $\mathrm{Na}$ ture 523: 592-596. doi:10.1038/nature14467

Baker DA, McFarland K, Lake RW, Shen H, Tang XC, Toda S, Kalivas P. 2003. Neuroadaptations in cystine-glutamate exchange underlie cocaine relapse. Nat Neurosci 6: 743-749. doi: $10.1038 / \mathrm{nn} 1069$

Barria A, Malinow R. 2002. Subunit-specific NMDA receptor trafficking to synapses. Neuron 35: 345-353. doi:10 .1016/S0896-6273(02)00776-6

Barria A, Malinow R. 2005. NMDA receptor subunit composition controls synaptic plasticity by regulating binding to CaMKII. Neuron 48: 289-301. doi:10.1016/j.neuron .2005 .08 .034

Barria A, Muller D, Derkach V, Griffith LC, Soderling TR. 1997. Regulatory phosphorylation of AMPA-type glutamate receptors by CaM-KII during long-term potentiation. Science 276: 2042-2045. doi:10.1126/science.276 .5321 .2042

Barrot M, Olivier JDA, Perrotti LI, DiLeone RJ, Berton O, Eisch AJ, Impey S, Storm DR, Neve RL, Yin JC, et al. 2002. CREB activity in the nucleus accumbens shell controls gating of behavioral responses to emotional stimuli. Proc Natl Acad Sci 99: 11435-11440. doi:10.1073/pnas .172091899

Benneyworth MA, Hearing MC, Asp AJ, Madayag A, Ingebretson AE, Schmidt CE, Silvis KA, Larson EB, Ebner SR, Thomas MJ. 2019. Synaptic depotentiation and mGluR5 activity in the nucleus accumbens drive cocaine-primed reinstatement of place preference. J Neurosci 39: 47854796. doi:10.1523/jneurosci.3020-17.2019 
W.J. Wright and Y. Dong

Bibb JA, Chen J, Taylor JR, Svenningsson P, Nishi A, Snyder GL, Yan Z, Sagawa ZK, Ouimet CC, Nairn AC, et al. 2001. Effects of chronic exposure to cocaine are regulated by the neuronal protein Cdk5. Nature 410: 376-380. doi:10 $.1038 / 35066591$

Bock R, Shin JH, Kaplan AR, Dobi A, Markey E, Kramer PF, Gremel CM, Christensen CH, Adrover MF, Alvarez VA. 2013. Strengthening the accumbal indirect pathway promotes resilience to compulsive cocaine use. Nat Neurosci 16: 632-638. doi:10.1038/nn.3369

Bocklisch C, Pascoli V, Wong JCY, House DRC, Yvon C, De Roo M, Tan KR, Lüscher C. 2013. Cocaine disinhibits dopamine neurons by potentiation of GABA transmission in the ventral tegmental area. Science 341: 15211525. doi:10.1126/science.1237059

Boudreau AC, Wolf ME. 2005. Behavioral sensitization to cocaine is associated with increased AMPA receptor surface expression in the nucleus accumbens. J Neurosci 25: 9144-9151. doi:10.1523/jneurosci.2252-05.2005

Boudreau AC, Reimers JM, Milovanovic M, Wolf ME. 2007. Cell surface AMPA receptors in the rat nucleus accumbens increase during cocaine withdrawal but internalize after cocaine challenge in association with altered activation of mitogen-activated protein kinases. J Neurosci 27: 10621-10635. doi:10.1523/jneurosci.2163-07.2007

Boudreau AC, Ferrario CR, Glucksman MJ, Wolf ME. 2009. Signaling pathway adaptations and novel protein kinase A substrates related to behavioral sensitization to cocaine. J Neurochem 110: 363-377. doi:10.1111/j.1471-4159.2009 $.06140 . \mathrm{x}$

Britt JP, Benaliouad F, McDevitt RA, Stuber GD, Wise RA, Bonci A. 2012. Synaptic and behavioral profile of multiple glutamatergic inputs to the nucleus accumbens. Neuron 76: 790-803. doi:10.1016/j.neuron.2012.09.040

Brown MTC, Bellone C, Mameli M, Labouèbe G, Bocklisch C, Balland B, Dahan L, Luján R, Deisseroth K, Lüscher C. 2010. Drug-driven AMPA receptor redistribution mimicked by selective dopamine neuron stimulation. PLoS ONE 5: e15870. doi:10.1371/journal.pone.0015870

Brown TE, Lee BR, Mu P, Ferguson D, Dietz D, Ohnishi YN, Lin Y, Suska A, Ishikawa M, Huang YH, et al. 2011. A silent synapse-based mechanism for cocaine-induced locomotor sensitization. J Neurosci 31: 8163-8174. doi:10 .1523/jneurosci.0016-11.2011

Caine SB, Thomsen M, Gabriel KI, Berkowitz JS, Gold LH, Koob GF, Tonegawa S, Zhang J, Xu M. 2007. Lack of self-administration of cocaine in dopamine D1 receptor knock-out mice. J Neurosci 27: 13140-13150. doi:10 .1523/jneurosci.2284-07.2007

Calipari ES, Bagot RC, Purushothaman I, Davidson TJ, Yorgason JT, Peña CJ, Walker DM, Pirpinias ST, Guise KG, Ramakrishnan C, et al. 2016. In vivo imaging identifies temporal signature of D1 and D2 medium spiny neurons in cocaine reward. Proc Natl Acad Sci 113: 2726-2731. doi:10.1073/pnas.1521238113

Cameron CM, Murugan M, Choi JY, Engel EA, Witten IB. 2019. Increased cocaine motivation is associated with degraded spatial and temporal representations in IL-NAc neurons. Neuron 103: 80-91.e7. doi:10.1016/j.neuron 2019.04.015

Carlezon WA, Thome J, Olson VG, Lane-Ladd SB, Brodkin ES, Hiroi N, Duman RS, Neve RL, Nestler EJ. 1998. Reg- ulation of cocaine reward by CREB. Science 282: 22722275. doi:10.1126/science.282.5397.2272

Carlezon WA, Duman RS, Nestler EJ. 2005. The many faces of CREB. Trends Neurosci 28: 436-445. doi:10.1016/j.tins .2005 .06 .005

Cervo L, Mukherjee S, Bertaglia A, Samanin R. 1997. Protein kinases $\mathrm{A}$ and $\mathrm{C}$ are involved in the mechanisms underlying consolidation of cocaine place conditioning. Brain Res 775: 30-36. doi:10.1016/S0006-8993(97)00866-4

Chao J, Nestler EJ. 2004. Molecular neurobiology of drug addiction. Annu Rev Med 55: 113-132. doi:10.1146/an nurev.med.55.091902.103730

Chao SZ, Ariano MA, Peterson DA, Wolf ME. 2002a. D1 dopamine receptor stimulation increases GluR1 surface expression in nucleus accumbens neurons. J Neurochem 83: 704-712. doi:10.1046/j.1471-4159.2002.01164.x

Chao SZ, Lu W, Lee HK, Huganir RL, Wolf ME. 2002b. D dopamine receptor stimulation increases GluR1 phosphorylation in postnatal nucleus accumbens cultures. $J$ Neurochem 81: 984-992. doi:10.1046/j.1471-4159.2002 .00877.x

Cheng Y, Huang CCY, Ma T, Wei X, Wang X, Lu J, Wang J. 2016. Distinct synaptic strengthening of the striatal direct and indirect pathways drives alcohol consumption. Biol Psychiatry 81: 918-929. doi:10.1016/j.biopsych.2016.05 .016

Cichon J, Gan WB. 2015. Branch-specific dendritic $\mathrm{Ca}^{2+}$ spikes cause persistent synaptic plasticity. Nature 520: 180-185. doi:10.1038/nature14251

Conrad KL, Tseng KY, Uejima JL, Reimers JM, Heng LJ, Shaham Y, Marinelli M, Wolf ME. 2008. Formation of accumbens GluR2-lacking AMPA receptors mediates incubation of cocaine craving. Nature 454: 118-121. doi:10 .1038/nature06995

Cornish JL, Kalivas P. 2000. Glutamate transmission in the nucleus accumbens mediates relapse in cocaine addiction. J Neurosci 20: RC89. doi:10.1523/jneurosci.20-15-j0006 .2000

Creed M, Ntamati NR, Chandra R, Lobo MK, Lüscher C. 2016. Convergence of reinforcing and anhedonic cocaine effects in the ventral pallidum. Neuron 92: 214-226. doi:10.1016/j.neuron.2016.09.001

Damez-Werno D, LaPlant Q, Sun H, Scobie KN, Dietz DM, Walker IM, Koo JW, Vialou VF, Mouzon E, Russo SJ, et al. 2012. Drug experience epigenetically primes Fosb gene inducibility in rat nucleus accumbens. J Neurosci 32: 10267-10272. doi:10.1523/jneurosci.1290-12.2012

Davis GW. 2013. Homeostatic signaling and the stabilization of neural function. Neuron 80: 718-728. doi:10.1016/j .neuron.2013.09.044

Derkach VA, Oh MC, Guire ES, Soderling TR. 2007. Regulatory mechanisms of AMPA receptors in synaptic plasticity. Nat Rev Neurosci 8: 101-113. doi:10.1038/nrn2055

Di Ciano P. 2004. Direct interactions between the basolateral amygdala and nucleus accumbens core underlie cocaineseeking behavior by rats. J Neurosci 24: 7167-7173. doi:10 .1523/jneurosci.1581-04.2004

Di Chiara G, Imperato A. 1988. Drugs abused by humans preferentially increase synaptic dopamine concentrations in the mesolimbic system of freely moving rats. Proc Natl Acad Sci 85: 5274-5278. doi:10.1073/pnas.85.14.5274 
Dobi A, Seabold GK, Christensen CH, Bock R, Alvarez VA. 2011. Cocaine-induced plasticity in the nucleus accumbens is cell specific and develops without prolonged withdrawal. J Neurosci 31: 1895-1904. doi:10.1523/jneurosci .5375-10.2011

Dong Y, Nestler EJ. 2014. The neural rejuvenation hypothesis of cocaine addiction. Trends Pharmacol Sci 35: 374383. doi:10.1016/j.tips.2014.05.005

Durand GM, Kovalchuk Y, Konnerth A. 1996. Long-term potentiation and functional synapse induction in developing hippocampus. Nature 381: 71-75. doi:10.1038/ $381071 \mathrm{a} 0$

Ehrlich I, Klein M, Rumpel S, Malinow R. 2007. PSD-95 is required for activity-driven synapse stabilization. Proc Natl Acad Sci 104: 4176-4181. doi:10.1073/pnas.060 9307104

El-Husseini AE, Schnell E, Chetkovich DM, Nicoll RA, Bredt DS. 2000. PSD-95 involvement in maturation of excitatory synapses. Science 290: 1364-1368.

Esteban JA, Shi SH, Wilson C, Nuriya M, Huganir RL, Malinow R. 2003. PKA phosphorylation of AMPA receptor subunits controls synaptic trafficking underlying plasticity. Nat Neurosci 6: 136-143. doi:10.1038/nn997

Everitt BJ, Robbins TW. 2016. Drug addiction: updating actions to habits to compulsions ten years on. Annu Rev Psychol 67: 23-50. doi:10.1146/annurev-psych-122414033457

Favaro PD, Huang X, Hosang L, Stodieck S, Cui L, Liu Y, Engelhardt KA, Schmitz F, Dong Y, Löwel S, et al. 2018. An opposing function of paralogs in balancing developmental synapse maturation. PLoS Biol 16: e2006838. doi:10.1371/journal.pbio.2006838

Ferrario CR, Loweth JA, Milovanovic M, Ford KA, Galiñanes GL, Heng LJ, Tseng KY, Wolf ME. 2011. Alterations in AMPA receptor subunits and TARPs in the rat nucleus accumbens related to the formation of $\mathrm{Ca}^{2+}$-permeable AMPA receptors during the incubation of cocaine craving. Neuropharmacology 61: 1141-1151. doi:10.1016/j .neuropharm.2011.01.021

Fu M, Yu X, Lu J, Zuo Y. 2012. Repetitive motor learning induces coordinated formation of clustered dendritic spines in vivo. Nature 482: 92-95. doi:10.1038/na ture10844

Gambrill AC, Barria A. 2011. NMDA receptor subunit composition controls synaptogenesis and synapse stabilization. Proc Natl Acad Sci 108: 5855-5860. doi:10.1073/ pnas. 1012676108

Gao C, Sun X, Wolf ME. 2006. Activation of D1 dopamine receptors increases surface expression of AMPA receptors and facilitates their synaptic incorporation in cultured hippocampal neurons. J Neurochem 98: 1664-1677. doi:10.1111/j.1471-4159.2006.03999.x

Gerfen CR, Engber TM, Mahan LC, Susel Z, Chase TN, Monsma FJ, Sibley DR. 1990. D1 and D2 dopamine receptor-regulated gene expression of striatonigral and striatopallidal neurons. Science 250: 1429-1432. doi:10 $.1126 /$ science. 2147780

Gibson GD, Prasad AA, Jean-Richard-Dit-Bressel P, Yau JOY, Millan EZ, Liu Y, Campbell EJ, Lim J, Marchant NJ, Power JM, et al. 2018. Distinct accumbens shell output pathways promote versus prevent relapse to alcohol seek- ing. Neuron 98: 512-520.e6. doi:10.1016/j.neuron.2018 .03 .033

Giese KP, Fedorov NB, Filipkowski RK, Silva AJ. 1998. Autophosphorylation at Thr286 of the $\alpha$ calcium-calmodulin kinase II in LTP and learning. Science 279: 870-873. doi:10.1126/science.279.5352.870

Gipson CD, Kupchik YM, Shen H, Reissner KJ, Thomas CA, Kalivas PW. 2013. Relapse induced by cues predicting cocaine depends on rapid, transient synaptic potentiation. Neuron 77: 867-872. doi:10.1016/j.neuron.2013.01 .005

Girault J, Valjent E, Caboche J, Herve D. 2007. ERK2: a logical AND gate critical for drug-induced plasticity? Curr Opin Pharmacol 7: 77-85. doi:10.1016/j.coph.2006 .08 .012

Gray JA, Shi Y, Usui H, During MJ, Sakimura K, Nicoll RA. 2011. Distinct modes of AMPA receptor suppression at developing synapses by GluN2A and GluN2B: single-cell NMDA receptor subunit deletion in vivo. Neuron 71: 1085-1101. doi:10.1016/j.neuron.2011.08.007

Graziane NM, Sun S, Wright WJ, Jang D, Liu Z, Huang YH, Nestler EJ, Wang YT, Schlüter OM, Dong Y. 2016. Opposing mechanisms mediate morphine- and cocaine-induced generation of silent synapses. Nat Neurosci 19: 915-925. doi:10.1038/nn.4313

Grimm JW, Hope BT, Wise RA, Shaham Y. 2001. Neuroadaptation. Incubation of cocaine craving after withdrawal. Nature 412: 141-142. doi:10.1038/35084134

Grueter BA, Robison AJ, Neve RL, Nestler EJ, Malenka RC. 2013. $\triangle$ FosB differentially modulates nucleus accumbens direct and indirect pathway function. Proc Natl Acad Sci 110: 1923-1928. doi:10.1073/pnas.1221742110

Guire ES, Oh MC, Soderling TR, Derkach VA. 2008. Recruitment of calcium-permeable AMPA receptors during synaptic potentiation is regulated by CaM-kinase I. J Neurosci 28: 6000-6009. doi:10.1523/jneurosci.0384-08.2008

Haight JL, Fraser KM, Akil H, Flagel SB. 2015. Lesions of the paraventricular nucleus of the thalamus differentially affect sign- and goal-tracking conditioned responses. Eur J Neurosci 42: 2478-2488. doi:10.1111/ejn.13031

Hanse E, Seth H, Riebe I. 2013. AMPA-silent synapses in brain development and pathology. Nat Rev Neurosci 14 839-850. doi:10.1038/nrn3642

Hayashi Y, Shi SH, Esteban JA, Piccini A, Poncer JC, Malinow R. 2000. Driving AMPA receptors into synapses by LTP and CaMKII: requirement for GluR1 and PDZ domain interaction. Science 287: 2262-2267. doi:10.1126/ science.287.5461.2262

Hayashi-Takagi A, Yagishita S, Nakamura M, Shirai F, Wu YI, Loshbaugh AL, Kuhlman B, Hahn KM, Kasai H. 2015 Labelling and optical erasure of synaptic memory traces in the motor cortex. Nature 525: 333-338. doi:10.1038/ nature 15257

Holtmaat A, Svoboda K. 2009. Experience-dependent structural synaptic plasticity in the mammalian brain. Nat Rev Neurosci 10: 647-658. doi:10.1038/nrn2699

Holtmaat A, Wilbrecht L, Knott GW, Welker E, Svoboda K. 2006. Experience-dependent and cell-type-specific spine growth in the neocortex. Nature 441: 979-983. doi:10 $.1038 /$ nature 04783 
W.J. Wright and Y. Dong

Hope BT, Nye HE, Kelz MB, Self DW, Iadarola MJ, Nakabeppu Y, Duman RS, Nestler EJ. 1994. Induction of a long-lasting AP-1 complex composed of altered Fos-like proteins in brain by chronic cocaine and other chronic treatments. Neuron 13: 1235-1244. doi:10.1016/08966273(94)90061-2

Huang YH, Lin Y, Mu P, Lee BR, Brown TE, Wayman G, Marie H, Liu W, Yan Z, Sorg BA, et al. 2009. In vivo cocaine experience generates silent synapses. Neuron 63: 40-47. doi:10.1016/j.neuron.2009.06.007

Huganir RL, Nicoll RA. 2013. AMPARs and synaptic plasticity: the last 25 years. Neuron 80: 704-717. doi:10.1016/j .neuron.2013.10.025

Huntley GW. 2012. Synaptic circuit remodelling by matrix metalloproteinases in health and disease. Nat Rev Neurosci 13: 743-757. doi:10.1038/nrn3320

Hyman SE, Malenka RC, Nestler EJ. 2006. Neural mechanisms of addiction: the role of reward-related learning and memory. Annu Rev Neurosci 29: 565-598. doi:10 .1146/annurev.neuro.29.051605.113009

Ishikawa A, Ambroggi F, Nicola SM, Fields HL. 2008. Dorsomedial prefrontal cortex contribution to behavioral and nucleus accumbens neuronal responses to incentive cues. J Neurosci 28: 5088-5098. doi:10.1523/jneurosci.0253-08 .2008

Ishikawa M, Mu P, Moyer JT, Wolf JA, Quock RM, Davies NM, Hu XT, Schlüter OM, Dong Y. 2009. Homeostatic synapse-driven membrane plasticity in nucleus accumbens neurons. J Neurosci 29: 5820-5831. doi:10.1523/ jneurosci.5703-08.2009

Ito R, Robbins TW, Pennartz CM, Everitt BJ. 2008. Functional interaction between the hippocampus and nucleus accumbens shell is necessary for the acquisition of appetitive spatial context conditioning. J Neurosci 28: 69506959. doi:10.1523/jneurosci.1615-08.2008

Joffe ME, Grueter BA. 2016. Cocaine experience enhances thalamo-accumbens $N$-methyl-D-aspartate receptor function. Biol Psychiatry 80: 671-681. doi:10.1016/j.biopsych 2016.04.002

Kalivas PW. 2005. How do we determine which drug-induced neuroplastic changes are important? Nat Neurosci 8: 1440-1441. doi:10.1038/nn1105-1440

Kalivas P. 2009. The glutamate homeostasis hypothesis of addiction. Nat Rev Neurosci 10: 561-572. doi:10.1038/ nrn2515

Kerchner GA, Nicoll RA. 2008. Silent synapses and the emergence of a postsynaptic mechanism for LTP. Nat Rev Neurosci 9: 813-825. doi:10.1038/nrn2501

Kim J, Park BH, Lee JH, Park SK, Kim JH. 2011. Cell typespecific alterations in the nucleus accumbens by repeated exposures to cocaine. Biol Psychiatry 69: 1026-1034. doi:10.1016/j.biopsych.2011.01.013

Kirouac GJ. 2015. Placing the paraventricular nucleus of the thalamus within the brain circuits that control behavior. Neurosci Biobehav Rev 56: 315-329. doi:10.1016/j.neu biorev.2015.08.005

Kirson ED, Yaari Y. 1996. Synaptic NMDA receptors in developing mouse hippocampal neurones: functional properties and sensitivity to ifenprodil. J Physiol 497: 437-455. doi:10.1113/jphysiol.1996.sp021779
Knott GW, Holtmaat A, Wilbrecht L, Welker E, Svoboda K. 2006. Spine growth precedes synapse formation in the adult neocortex in vivo. Nat Neurosci 9: 1117-1124. doi:10.1038/nn1747

Kourrich S, Rothwell PE, Klug JR, Thomas MJ. 2007. Cocaine experience controls bidirectional synaptic plasticity in the nucleus accumbens. J Neurosci 27: 7921-7928. doi:10.1523/jneurosci.1859-07.2007

Kupchik YM, Brown RM, Heinsbroek JA, Lobo MK, Schwartz DJ, Kalivas P. 2015. Coding the direct/indirect pathways by D1 and D2 receptors is not valid for accumbens projections. Nat Neurosci 18: 1230-1232. doi:10 $.1038 / \mathrm{nn} .4068$

Lansink CS, Goltstein PM, Lankelma JV, McNaughton BL, Pennartz CMA. 2009. Hippocampus leads ventral striatum in replay of place-reward information. PLoS Biol 7: e1000173. doi:10.1371/journal.pbio.1000173

Lee HK, Takamiya K, Han JS, Man H, Kim CH, Rumbaugh G, Yu S, Ding L, He C, Petralia RS, et al. 2003. Phosphorylation of the AMPA receptor GluR1 subunit is required for synaptic plasticity and retention of spatial memory. Cell 112: 631-643. doi:10.1016/S0092-8674(03)00122-3

Lee BR, Ma YY, Huang YH, Wang X, Otaka M, Ishikawa M, Neumann PA, Graziane NM, Brown TE, Suska A, et al. 2013. Maturation of silent synapses in amygdala-accumbens projection contributes to incubation of cocaine craving. Nat Neurosci 16: 1644-1651. doi:10.1038/nn.3533

Lisman J, Yasuda R, Raghavachari S. 2012. Mechanisms of CaMKII action in long-term potentiation. Nat Rev Neurosci 13: 169-182. doi:10.1038/nrn3192

Lobo MK, Covington HE, Chaudhury D, Friedman AK, Sun H, Damez-Werno D, Dietz DM, Zaman S, Koo JW, Kennedy PJ, et al. 2010. Cell type-specific loss of BDNF signaling mimics optogenetic control of cocaine reward. Science 330: 385-390. doi:10.1126/science.1188472

Lobo MK, Zaman S, Damez-Werno DM, Koo JW, Bagot RC, DiNieri JA, Nugent A, Finkel E, Chaudhury D, Chandra $\mathrm{R}$, et al. 2013. $\Delta$ FosB induction in striatal medium spiny neuron subtypes in response to chronic pharmacological, emotional, and optogenetic stimuli. J Neurosci 33: 1838118395. doi:10.1523/jneurosci.1875-13.2013

Loweth JA, Li D, Cortright JJ, Wilke G, Jeyifous O, Neve RL, Bayer KU, Vezina P. 2013. Persistent reversal of enhanced amphetamine intake by transient CaMKII inhibition. J Neurosci 33: 1411-1416. doi:10.1523/jneurosci.4386-13 .2013

Loweth JA, Scheyer AF, Milovanovic M, Lacrosse AL, FloresBarrera E, Werner CT, Li X, Ford KA, Le T, Olive MF, et al. 2014. Synaptic depression via mGluR1 positive allosteric modulation suppresses cue-induced cocaine craving. Nat Neurosci 17: 73-80. doi:10.1038/nn.3590

Loweth JA, Reimers JM, Caccamise A, Stefanik MT, Woo KKY, Chauhan NM, Werner CT, Wolf ME. 2018. mGlu1 tonically regulates levels of calcium-permeable AMPA receptors in cultured nucleus accumbens neurons through retinoic acid signaling and protein translation. Eur J Neurosci 60: 308-315.

Lu L, Grimm JW, Shaham Y, Hope BT. 2003. Molecular neuroadaptations in the accumbens and ventral tegmental area during the first 90 days of forced abstinence from cocaine self-administration in rats. J Neurochem 85: 1604-1613. doi:10.1046/j.1471-4159.2003.01824.x 
Lu L, Koya E, Zhai H, Hope BT, Shaham Y. 2006. Role of ERK in cocaine addiction. Trends Neurosci 29: 695-703. doi:10.1016/j.tins.2006.10.005

Lu W, Isozaki K, Roche KW, Nicoll RA. 2010. Synaptic targeting of AMPA receptors is regulated by a CaMKII site in the first intracellular loop of GluA1. Proc Natl Acad Sci 107: 22266-22271. doi:10.1073/pnas.1016289107

Lynch WJ, Taylor JR. 2005. Decreased motivation following cocaine self-administration under extended access conditions: effects of sex and ovarian hormones. Neuropsychopharmacology 30: 927-935. doi:10.1038/sj.npp.1300656

Ma YY, Lee BR, Wang X, Guo C, Liu L, Cui R, Lan Y, BalcitaPedicino JJ, Wolf ME, Sesack SR, et al. 2014. Bidirectional modulation of incubation of cocaine craving by silent synapse-based remodeling of prefrontal cortex to accumbens projections. Neuron 83: 1453-1467. doi:10.1016/j .neuron.2014.08.023

Ma YY, Wang X, Huang Y, Marie H, Nestler EJ, Schlüter OM, Dong Y. 2016. Re-silencing of silent synapses unmasks anti-relapse effects of environmental enrichment. Proc Natl Acad Sci 113: 5089-5094. doi:10.1073/pnas .1524739113

MacAskill AF, Cassel JM, Carter AG. 2014. Cocaine exposure reorganizes cell type- and input-specific connectivity in the nucleus accumbens. Nat Neurosci 17: 1198-1207. doi:10.1038/nn.3783

Malenka RC, Kauer JA, Zucker RS, Nicoll RA. 1988. Postsynaptic calcium is sufficient for potentiation of hippocampal synaptic transmission. Science 242: 81-84. doi:10 .1126/science. 2845577

Malenka RC, Kauer JA, Perkel DJ, Mauk MD, Kelly PT, Nicoll RA, Waxham MN. 1989. An essential role for postsynaptic calmodulin and protein kinase activity in longterm potentiation. Nature 340: 554-557. doi:10.1038/ 340554a0

Maletic-Savatic M, Malinow R, Svoboda K. 1999. Rapid dendritic morphogenesis in CA1 hippocampal dendrites induced by synaptic activity. Science 283: 1923-1927. doi:10 $.1126 /$ science.283.5409.1923

Malinow R, Schulman H, Tsien RW. 1989. Inhibition of postsynaptic PKC or CaMKII blocks induction but not expression of LTP. Science 245: 862-866. doi:10.1126/sci ence. 2549638

Mameli M, Halbout B, Creton C, Engblom D, Parkitna JR, Spanagel R, Lüscher C. 2009. Cocaine-evoked synaptic plasticity: persistence in the VTA triggers adaptations in the NAc. Nat Neurosci 12: 1036-1041. doi:10.1038/nn .2367

Mangiavacchi S, Wolf ME. 2004. D1 dopamine receptor stimulation increases the rate of AMPA receptor insertion onto the surface of cultured nucleus accumbens neurons through a pathway dependent on protein kinase A. J Neurochem 88: 1261-1271. doi:10.1046/j.1471-4159.2003 .02248.x

Marie H, Morishita W, Yu X, Calakos N, Malenka RC. 2005. Generation of silent synapses by acute in vivo expression of CaMKIV and CREB. Neuron 45: 741-752. doi:10 .1016/j.neuron.2005.01.039

Matsuzaki M, Ellis-Davies GC, Nemoto T, Miyashita Y, Iino M, Kasai H. 2001. Dendritic spine geometry is critical for AMPA receptor expression in hippocampal CA1 pyrami- dal neurons. Nat Neurosci 4: 1086-1092. doi:10.1038/ nn736

Matsuzaki M, Honkura N, Ellis-Davies GCR, Kasai H. 2004. Structural basis of long-term potentiation in single dendritic spines. Nature 429: 761-766. doi:10.1038/na ture02617

Matta JA, Ashby MC, Sanz-Clemente A, Roche KW, Isaac JTR. 2011. mGluR5 and NMDA receptors drive the experience- and activity-dependent NMDA receptor NR2B to NR2A subunit switch. Neuron 70: 339-351. doi:10 .1016/j.neuron.2011.02.045

Mattson BJ, Bossert JM, Simmons DE, Nozaki N, Nagarkar D, Kreuter JD, Hope BT. 2005. Cocaine-induced CREB phosphorylation in nucleus accumbens of cocaine-sensitized rats is enabled by enhanced activation of extracellular signal-related kinase, but not protein kinase A. J Neurochem 95: 1481-1494. doi:10.1111/j 1471-4159.2005.03500.x

McClung CA, Nestler EJ. 2003. Regulation of gene expression and cocaine reward by CREB and $\triangle F$ FosB. Nat Neurosci 6: 1208-1215. doi:10.1038/nn1143

McCutcheon JE, Loweth JA, Ford KA, Marinelli M, Wolf ME, Tseng KY. 2011a. Group I mGluR activation reverses cocaine-induced accumulation of calcium-permeable AMPA receptors in nucleus accumbens synapses via a protein kinase C-dependent mechanism. J Neurosci 31: 14536-14541. doi:10.1523/jneurosci.3625-11.2011

McCutcheon JE, Wang X, Tseng KY, Wolf ME, Marinelli M. 2011b. Calcium-permeable AMPA receptors are present in nucleus accumbens synapses after prolonged withdrawal from cocaine self-administration but not experimenter-administered cocaine. J Neurosci 31: 5737-5743. doi:10.1523/jneurosci.0350-11.2011

McFarland K, Kalivas P. 2001. The circuitry mediating cocaine-induced reinstatement of drug-seeking behavior. J Neurosci 21: 8655-8663. doi:10.1523/jneurosci.21-2108655.2001

McFarland K, Lapish CC, Kalivas P. 2003. Prefrontal glutamate release into the core of the nucleus accumbens mediates cocaine-induced reinstatement of drug-seeking behavior. J Neurosci 23: 3531-3537. doi:10.1523/jneuro sci.23-08-03531.2003

Mogenson GJ, Jones DL, Yim CY. 1980. From motivation to action: functional interface between the limbic system and the motor system. Prog Neurobiol 14: 69-97. doi:10.1016/ 0301-0082(80)90018-0

Monyer H, Burnashev N, Laurie DJ, Sakmann B, Seeburg PH. 1994. Developmental and regional expression in the rat brain and functional properties of four NMDA receptors. Neuron 12: 529-540. doi:10.1016/0896-6273(94) 90210-0

Morita D, Rah JC, Isaac JTR. 2013. Incorporation of inwardly rectifying AMPA receptors at silent synapses during hippocampal long-term potentiation. Philos Trans $R$ Soc Lond B Biol Sci 369: 20130156. doi:10.1098/rstb.2013 .0156

Moussawi K, Zhou W, Shen H, Reichel CM, See RE, Carr DB, Kalivas P. 2011. Reversing cocaine-induced synaptic potentiation provides enduring protection from relapse. Proc Natl Acad Sci 108: 385-390. doi:10.1073/pnas 1011265108 
W.J. Wright and Y. Dong

Mulholland PJ, Chandler LJ, Kalivas P. 2016. Signals from the fourth dimension regulate drug relapse. Trends $\mathrm{Neu}$ rosci 39: 472-485. doi:10.1016/j.tins.2016.04.007

Murphy DD, Segal M. 1997. Morphological plasticity of dendritic spines in central neurons is mediated by activation of cAMP response element binding protein. Proc Natl Acad Sci 94: 1482-1487. doi:10.1073/pnas.94.4.1482

Murugan M, Jang HJ, Park M, Miller EM, Cox J, Taliaferro JP, Parker NF, Bhave V, Hur H, Liang Y, et al. 2017. Combined social and spatial coding in a descending projection from the prefrontal cortex. Cell 171: 1663-1677. e16. doi:10.1016/j.cell.2017.11.002

Muschamp JW, Carlezon WA. 2013. Roles of nucleus accumbens CREB and dynorphin in dysregulation of motivation. Cold Spring Harb Perspect Med 3: a012005. doi:10 $.1101 /$ cshperspect.a012005

Nakayama K, Kiyosue K, Taguchi T. 2005. Diminished neuronal activity increases neuron-neuron connectivity underlying silent synapse formation and the rapid conversion of silent to functional synapses. J Neurosci 25: 4040-4051. doi:10.1523/jneurosci.4115-04.2005

Neumann PA, Wang Y, Yan Y, Wang Y, Ishikawa M, Cui R, Huang YH, Sesack SR, Schlüter OM, Dong Y. 2016. Cocaine-induced synaptic alterations in thalamus to nucleus accumbens projection. Neuropsychopharmacology 41: 2399-2410. doi:10.1038/npp.2016.52

Norrholm SD, Bibb JA, Nestler EJ, Ouimet CC, Taylor JR Greengard P. 2003. Cocaine-induced proliferation of dendritic spines in nucleus accumbens is dependent on the activity of cyclin-dependent kinase-5. Neuroscience 116: $19-22$.

O'Connor EC, Kremer Y, Lefort S, Harada M, Pascoli V, Rohner C, Lüscher C. 2015. Accumbal D1R neurons projecting to lateral hypothalamus authorize feeding. Neuron 88: 553-564. doi:10.1016/j.neuron.2015.09.038

Opazo P, Labrecque S, Tigaret CM, Frouin A, Wiseman PW, De Koninck P, Choquet D. 2010. CaMKII triggers the diffusional trapping of surface AMPARs through phosphorylation of Stargazin. Neuron 67: 239-252. doi:10 $.1016 /$ j.neuron.2010.06.007

Ortinski PI, Vassoler FM, Carlson GC, Pierce RC. 2012 Temporally dependent changes in cocaine-induced synaptic plasticity in the nucleus accumbens shell are reversed by D1-like dopamine receptor stimulation. $\mathrm{Neu}$ ropsychopharmacology 37: 1671-1682. doi:10.1038/npp .2012 .12

Park P, Sanderson TM, Amici M, Choi SL, Bortolotto ZA, Zhuo M, Kaang BK, Collingridge GL. 2016. Calcium-permeable AMPA receptors mediate the induction of the protein kinase A-dependent component of long-term potentiation in the hippocampus. J Neurosci 36: 622-631. doi:10.1523/jneurosci.3625-15.2016

Pascoli V, Turiault M, Lüscher C. 2013. Reversal of cocaineevoked synaptic potentiation resets drug-induced adaptive behaviour. Nature 481: 71-75. doi:10.1038/nature 10709

Pascoli V, Terrier J, Espallergues J, Valjent E, O'Connor EC, Lüscher C. 2014. Contrasting forms of cocaine-evoked plasticity control components of relapse. Nature 509: 459-464. doi:10.1038/nature13257

Pascoli V, Terrier J, Hiver A, Lüscher C. 2015. Sufficiency of mesolimbic dopamine neuron stimulation for the pro- gression to addiction. Neuron 88: 1054-1066. doi:10 .1016/j.neuron.2015.10.017

Passafaro M, Piëch V, Sheng M. 2001. Subunit-specific temporal and spatial patterns of AMPA receptor exocytosis in hippocampal neurons. Nat Neurosci 4: 917-926. doi:10 1038/nn0901-917

Peters J, Kalivas P. 2006. The group II metabotropic glutamate receptor agonist, LY379268, inhibits both cocaineand food-seeking behavior in rats. Psychopharmacology 186: 143-149. doi:10.1007/s00213-006-0372-9

Peters J, LaLumiere RT, Kalivas PW. 2008. Infralimbic prefrontal cortex is responsible for inhibiting cocaine seeking in extinguished rats. J Neurosci 28: 6046-6053. doi:10 .1523/jneurosci.1045-08.2008

Petralia RS, Esteban JA, Wang YX, Partridge JG, Zhao HM, Wenthold RJ, Malinow R. 1999. Selective acquisition of AMPA receptors over postnatal development suggests a molecular basis for silent synapses. Nat Neurosci 2:31-36. doi: $10.1038 / 4532$

Phillips PEM, Stuber GD, Heien MLAV, Wightman RM, Carelli RM. 2003. Subsecond dopamine release promotes cocaine seeking. Nature 422: 614-618. doi:10.1038/na ture 01476

Pierce RC, Bell K, Duffy P, Kalivas P. 1996. Repeated cocaine augments excitatory amino acid transmission in the nucleus accumbens only in rats having developed behavioral sensitization. J Neurosci 16: 1550-1560. doi:10.1523/ jneurosci.16-04-01550.1996

Pierce RC, Reeder DC, Hicks J, Morgan ZR, Kalivas PW. 1998. Ibotenic acid lesions of the dorsal prefrontal cortex disrupt the expression of behavioral sensitization to cocaine. Neuroscience 82: 1103-1114. doi:10.1016/S03064522(97)00366-7

Pisanu A, Lecca D, Valentini V, Bahi A, Dreyer JL, Cacciapaglia F, Scifo A, Piras G, Cadoni C, Di Chiara G. 2015. Impairment of acquisition of intravenous cocaine self-administration by RNA-interference of dopamine D1-receptors in the nucleus accumbens shell. Neuropharmacology 89: 398-411. doi:10.1016/j.neuropharm .2014.10.018

Plant K, Pelkey KA, Bortolotto ZA, Morita D, Terashima A, McBain CJ, Collingridge GL, Isaac JTR. 2006. Transient incorporation of native GluR2-lacking AMPA receptors during hippocampal long-term potentiation. Nat Neurosci 9: 602-604. doi:10.1038/nn1678

Plattner F, Hernández A, Kistler TM, Pozo K, Zhong P, Yuen EY, Tan C, Hawasli AH, Cooke SF, Nishi A, et al. 2014. Memory enhancement by targeting Cdk5 regulation of NR2B. Neuron 81: 1070-1083. doi:10.1016/j.neuron .2014 .01 .022

Pomierny-Chamioło L, Rup K, Pomierny B, Niedzielska E, Kalivas P, Filip M. 2014. Metabotropic glutamatergic receptors and their ligands in drug addiction. Pharmacol Therapeut 142: 281-305. doi:10.1016/j.pharmthera.2013 .12 .012

Poncer JC, Esteban JA, Malinow R. 2002. Multiple mechanisms for the potentiation of AMPA receptor-mediated transmission by $\alpha-\mathrm{Ca}^{2+} /$ calmodulin-dependent protein kinase II. J Neurosci 22: 4406-4411. doi:10.1523/jneuro sci.22-11-04406.2002

Purgianto A, Scheyer AF, Loweth JA, Ford KA, Tseng KY, Wolf ME. 2013. Different adaptations in AMPA receptor 
transmission in the nucleus accumbens after short vs long access cocaine self-administration regimens. Neuropsychopharmacology 38: 1789-1797. doi:10.1038/npp.2013 .78

Reissner KJ, Gipson CD, Tran PK, Knackstedt LA, Scofield MD, Kalivas P. 2014. Glutamate transporter GLT-1 mediates $\mathrm{N}$-acetylcysteine inhibition of cocaine reinstatement. Addict Biol 20: 316-323. doi:10.1111/adb.12127

Roberts-Wolfe DJ, Kalivas PW. 2015. Glutamate transporter GLT-1 as a therapeutic target for substance use disorders. CNS Neurol Disord Drug Targets 14: 745-756. doi:10 .2174/1871527314666150529144655

Roberts-Wolfe D, Bobadilla AC, Heinsbroek JA, Neuhofer D, Kalivas P. 2018. Drug refraining and seeking potentiate synapses on distinct populations of accumbens medium spiny neurons. J Neurosci 38: 7100-7107. doi:10.1523/ jneurosci.0791-18.2018

Roberts-Wolfe DJ, Heinsbroek JA, Spencer SM, Bobadilla AC, Smith ACW, Gipson CD, Kalivas P. 2019. Transient synaptic potentiation in nucleus accumbens shell during refraining from cocaine seeking. Addict Biol 97: e12759. doi:10.1111/adb.12759

Robinson TE, Kolb B. 1999. Alterations in the morphology of dendrites and dendritic spines in the nucleus accumbens and prefrontal cortex following repeated treatment with amphetamine or cocaine. Eur J Neurosci 11: 15981604. doi:10.1046/j.1460-9568.1999.00576.x

Robinson TE, Gorny G, Mitton E, Kolb B. 2001. Cocaine self-administration alters the morphology of dendrites and dendritic spines in the nucleus accumbens and neocortex. Synapse 39: 257-266. doi:10.1002/1098-2396 (20010301)39:3<257::AID-SYN1007>3.0.CO;2-1

Robison AJ, Vialou V, Mazei-Robison M, Feng J, Kourrich S, Collins M, Wee S, Koob G, Turecki G, Neve R, et al. 2013. Behavioral and structural responses to chronic cocaine require a feedforward loop involving FosB and calcium/ calmodulin-dependent protein kinase II in the nucleus accumbens shell. J Neurosci 33: 4295-4307. doi:10 .1523/jneurosci.5192-12.2013

Russo SJ, Dietz DM, Dumitriu D, Morrison JH, Malenka RC, Nestler EJ. 2010. The addicted synapse: mechanisms of synaptic and structural plasticity in nucleus accumbens. Trends Neurosci 33: 267-276. doi:10.1016/j.tins.2010.02 .002

Scheyer AF, Wolf ME, Tseng KY. 2014. A protein synthesisdependent mechanism sustains calcium-permeable AMPA receptor transmission in nucleus accumbens synapses during withdrawal from cocaine self-administration. J Neurosci 34: 3095-3100. doi:10.1523/jneurosci .4940-13.2014

Self DW, Genova LM, Hope BT, Barnhart WJ, Spencer JJ, Nestler EJ. 1998. Involvement of cAMP-dependent protein kinase in the nucleus accumbens in cocaine self-administration and relapse of cocaine-seeking behavior. $J$ Neurosci 18: 1848-1859. doi:10.1523/jneurosci.18-0501848.1998

Sesack SR, Grace AA. 2010. Cortico-basal ganglia reward network: microcircuitry. Neuropsychopharmacology 35: 27-47. doi:10.1038/npp.2009.93

Shi S, Hayashi Y, Esteban JA, Malinow R. 2001. Subunitspecific rules governing AMPA receptor trafficking to synapses in hippocampal pyramidal neurons. Cell 105: 331-343. doi:10.1016/S0092-8674(01)00321-X

Shukla A, Beroun A, Panopoulou M, Neumann PA, Grant SG, Olive MF, Dong Y, Schlüter OM. 2017. Calcium-permeable AMPA receptors and silent synapses in cocaineconditioned place preference. EMBO J 36: 458-474. doi:10.15252/embj.201695465

Sjulson L, Peyrache A, Cumpelik A, Cassataro D, Buzsáki G. 2018. Cocaine place conditioning strengthens locationspecific hippocampal coupling to the nucleus accumbens. Neuron 98: 926-934.e5. doi:10.1016/j.neuron.2018.04 .015

Smith ACW, Kupchik YM, Scofield MD, Gipson CD, Wiggins A, Thomas CA, Kalivas P. 2014. Synaptic plasticity mediating cocaine relapse requires matrix metalloproteinases. Nat Neurosci 17: 1655-1657. doi:10.1038/nn.3846

Smith ACW, Scofield MD, Heinsbroek JA, Gipson CD, Neuhofer D, Roberts-Wolfe DJ, Spencer S, Stankeviciute NM, Smith R, Allen NP, et al. 2016. Accumbens nNOS interneurons regulate cocaine relapse. J Neurosci 37: 742-756. doi:10.1523/jneurosci.2673-16.2016

Spencer S, Garcia-Keller C, Roberts-Wolfe D, Heinsbroek JA, Mulvaney M, Sorrell A, Kalivas P. 2017. Cocaine use reverses striatal plasticity produced during cocaine seeking. Biol Psychiatry 81: 616-624. doi:10.1016/j.biopsych .2016 .08 .033

Stefanik MT, Kalivas P. 2013. Optogenetic dissection of basolateral amygdala projections during cue-induced reinstatement of cocaine seeking. Front Behav Neurosci 7: 213. doi:10.3389/fnbeh.2013.00213

Stefanik MT, Moussawi K, Kupchik YM, Smith KC, Miller RL, Huff ML, Deisseroth K, Kalivas P, LaLumiere RT. 2013. Optogenetic inhibition of cocaine seeking in rats. Addict Biol 18: 50-53. doi:10.1111/j.1369-1600.2012 .00479.x

Stefanik MT, Kupchik YM, Kalivas P. 2016. Optogenetic inhibition of cortical afferents in the nucleus accumbens simultaneously prevents cue-induced transient synaptic potentiation and cocaine-seeking behavior. Brain Struct Funct 221: 1681-1689. doi:10.1007/s00429-015-0997-8

Stefanik MT, Milovanovic M, Werner CT, Spainhour JCG, Wolf ME. 2018. Withdrawal from cocaine self-administration alters the regulation of protein translation in the nucleus accumbens. Biol Psychiatry 84: 223-232. doi:10 .1016/j.biopsych.2018.02.012

Stuber GD, Roitman MF, Phillips PEM, Carelli RM, Wightman RM. 2005. Rapid dopamine signaling in the nucleus accumbens during contingent and noncontingent cocaine administration. Neuropsychopharmacology 30: 853-863. doi:10.1038/sj.npp.1300619

Stuber GD, Sparta DR, Stamatakis AM, van Leeuwen WA, Hardjoprajitno JE, Cho SL, Tye KM, Kempadoo KA, Zhang F, Deisseroth K, et al. 2012. Excitatory transmission from the amygdala to nucleus accumbens facilitates reward seeking. Nature 475: 377-380. doi:10.1038/na ture10194

Südhof TC. 2018. Towards an understanding of synapse formation. Neuron 100: 276-293. doi:10.1016/j.neuron .2018 .09 .040

Sun X, Zhao Y, Wolf ME. 2005. Dopamine receptor stimulation modulates AMPA receptor synaptic insertion in 
W.J. Wright and Y. Dong

prefrontal cortex neurons. J Neurosci 25: 7342-7351. doi:10.1523/jneurosci.4603-04.2005

Surmeier DJ, Ding J, Day M, Wang Z, Shen W. 2007. D1 and D2 dopamine-receptor modulation of striatal glutamatergic signaling in striatal medium spiny neurons. Trends Neurosci 30: 228-235. doi:10.1016/j.tins.2007.03.008

Suska A, Lee BR, Huang YH, Dong Y, Schlüter OM. 2013. Selective presynaptic enhancement of the prefrontal cortex to nucleus accumbens pathway by cocaine. Proc Natl Acad Sci 110: 713-718. doi:10.1073/pnas.1206287110

Terrier J, Lüscher C, Pascoli V. 2016. Cell-type specific insertion of GluA2-lacking AMPARs with cocaine exposure leading to sensitization, cue-induced seeking, and incubation of craving. Neuropsychopharmacology 41: 17791789. doi:10.1038/npp.2015.345

Terwilliger RZ, Beitner-Johnson D, Sevarino KA, Crain SM, Nestler EJ. 1991. A general role for adaptations in G-proteins and the cyclic AMP system in mediating the chronic actions of morphine and cocaine on neuronal function Brain Res 548: 100-110. doi:10.1016/0006-8993(91) 91111-D

Thomas MJ, Beurrier C, Bonci A, Malenka RC. 2001. Longterm depression in the nucleus accumbens: a neural correlate of behavioral sensitization to cocaine. Nat Neurosci 4: 1217-1223. doi:10.1038/nn757

Tomita S, Stein V, Stocker TJ, Nicoll RA, Bredt DS. 2005 Bidirectional synaptic plasticity regulated by phosphorylation of stargazin-like TARPs. Neuron 45: 269-277. doi:10.1016/j.neuron.2005.01.009

Torregrossa MM, Taylor JR. 2013. Learning to forget: manipulating extinction and reconsolidation processes to treat addiction. Psychopharmacology (Berl) 226: 659672. doi:10.1007/s00213-012-2750-9

Tovar KR, Westbrook GL. 1999. The incorporation of NMDA receptors with a distinct subunit composition at nascent hippocampal synapses in vitro. J Neurosci 19: 4180-4188. doi:10.1523/jneurosci.19-10-04180.1999

Tronson NC, Taylor JR. 2007. Molecular mechanisms of memory reconsolidation. Nat Rev Neurosci 8: 262-275. doi:10.1038/nrn2090

Trouche S, Koren V, Doig NM, Ellender TJ, El-Gaby M, Lopes-dos-Santos V, Reeve HM, Perestenko PV, Garas FN, Magill PJ, et al. 2019. A hippocampus-accumbens tripartite neuronal motif guides appetitive memory in space. Cell 176: 1393-1406.e16. doi:10.1016/j.cell.2018 .12 .037

Turrigiano GG. 2008. The self-tuning neuron: synaptic scaling of excitatory synapses. Cell 135: 422-435. doi:10 $.1016 /$ j.cell.2008.10.008

Vialou V, Feng J, Robison AJ, Ku SM, Ferguson D, Scobie KN, Mazei-Robison MS, Mouzon E, Nestler EJ. 2012 Serum response factor and cAMP response element binding protein are both required for cocaine induction of FosB. J Neurosci 32: 7577-7584. doi:10.1523/jneurosci $.1381-12.2012$
Volkow ND, Wise RA, Baler R. 2017. The dopamine motive system: implications for drug and food addiction. Nat Rev Neurosci 18: 741-752. doi:10.1038/nrn.2017.130

Waites CL, Craig AM, Garner CC. 2005. Mechanisms of vertebrate synaptogenesis. Annu Rev Neurosci 28: 251274. doi:10.1146/annurev.neuro.27.070203.144336

Wang J, Ishikawa M, Yang Y, Otaka M, Kim JY, Gardner GR, Stefanik MT, Milovanovic M, Huang YH, Hell JW, et al. 2018. Cascades of homeostatic dysregulation promote incubation of cocaine craving. J Neurosci 38: 4316-4328. doi:10.1523/jneurosci.3291-17.2018

Werner CT, Stefanik MT, Milovanovic M, Caccamise A, Wolf ME. 2018. Protein translation in the nucleus accumbens is dysregulated during cocaine withdrawal and required for expression of incubation of cocaine craving. $J$ Neurosci 38: 2683-2697. doi:10.1523/jneurosci.2412-17 .2018

Wiggins A, Smith RJ, Shen H, Kalivas P. 2011. Integrins modulate relapse to cocaine-seeking. J Neurosci 31: 16177-16184. doi:10.1523/jneurosci.3816-11.2011

Wise RA. 2004. Dopamine, learning and motivation. Nat Rev Neurosci 5: 483-494. doi:10.1038/nrn1406

Wise RA, Rompre PP. 1989. Brain dopamine and reward. Annu Rev Psychol 40: 191-225. doi:10.1146/annurev.ps .40 .020189 .001203

Wolf ME. 2016. Synaptic mechanisms underlying persistent cocaine craving. Nat Rev Neurosci 17: 351-365. doi:10 1038/nrn.2016.39

Wolf ME, Tseng KY. 2012. Calcium-permeable AMPA receptors in the VTA and nucleus accumbens after cocaine exposure: when, how, and why? Front Mol Neurosci 5: 72.

Wright WJ, Graziane NM, Neumann P, Hamilton PJ, Gates HM, Fuerst L, Spenceley A, MacKinnon-Booth N, Iyer K, Huang YH, et al. 2019. Silent synapses dictate cocaine memory destabilization and reconsolidation. Nat Neurosci doi:10.1038/s41593-019-0537-6

Xu T, Yu X, Perlik AJ, Tobin WF, Zweig JA, Tennant K, Jones T, Zuo Y. 2009. Rapid formation and selective stabilization of synapses for enduring motor memories. Nature 462: 915-919. doi:10.1038/nature08389

Yang G, Pan F, Gan WB. 2009. Stably maintained dendritic spines are associated with lifelong memories. Nature 462: 920-924. doi:10.1038/nature08577

Yao WD, Gainetdinov RR, Arbuckle MI, Sotnikova TD, Cyr M, Beaulieu JM, Torres GE, Grant SGN, Caron MG. 2004 Identification of PSD-95 as a regulator of dopamine-mediated synaptic and behavioral plasticity. Neuron 41: 625638. doi:10.1016/S0896-6273(04)00048-0

Zhu Y, Wienecke CFR, Nachtrab G, Chen X. 2016. A thalamic input to the nucleus accumbens mediates opiate dependence. Nature 530: 219-222. doi:10.1038/nature 16954 


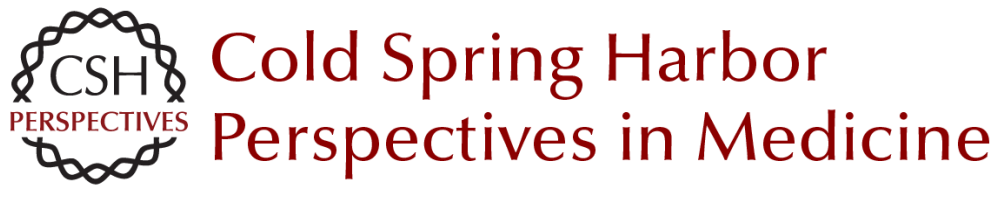

\title{
Psychostimulant-Induced Adaptations in Nucleus Accumbens Glutamatergic Transmission
}

\author{
William J. Wright and Yan Dong
}

Cold Spring Harb Perspect Med 2020; doi: 10.1101/cshperspect.a039255 originally published online January 21, 2020

\section{Subject Collection Addiction}

Developments from Bulk Optogenetics to

Single-Cell Strategies to Dissect the Neural

Circuits that Underlie Aberrant Motivational States Jose Rodriguez-Romaguera, Vijay M.K. Namboodiri, Marcus L. Basiri, et al.

Consequences of Parental Opioid Exposure on Neurophysiology, Behavior, and Health in the Next Generations

Fair M. Vassoler and Mathieu E. Wimmer

Animal Models of the Behavioral Symptoms of Substance Use Disorders Louk J.M.J. Vanderschuren and Serge H. Ahmed

Translational Research in Nicotine Addiction Miranda L. Fisher, James R. Pauly, Brett Froeliger, et al.

Neonatal Opioid Withdrawal Syndrome (NOWS): A Transgenerational Echo of the Opioid Crisis Andrew E. Weller, Richard C. Crist, Benjamin C. Reiner, et al.

Impairment of Synaptic Plasticity by Cannabis, $\Delta^{\mathbf{9}}$ -THC, and Synthetic Cannabinoids Alexander F. Hoffman, Eun-Kyung Hwang and Carl R. Lupica

Drug-Evoked Synaptic Plasticity of Excitatory Transmission in the Ventral Tegmental Area Camilla Bellone, Michael Loureiro and Christian Lüscher

Opioid-Induced Molecular and Cellular Plasticity of Ventral Tegmental Area Dopamine Neurons Marie A. Doyle and Michelle S. Mazei-Robison
The Persistent Challenge of Developing Addiction

Pharmacotherapies

Sarah E. Swinford-Jackson, Charles P. O'Brien,

Paul J. Kenny, et al.

Opioid Modulation of the Gut-Brain Axis in Opioid-Associated Comorbidities

Li Zhang and Sabita Roy

Epigenetics of Drug Addiction Andrew F. Stewart, Sasha L. Fulton and lan Maze

Genetic Vulnerability to Opioid Addiction Brian Reed and Mary Jeanne Kreek

Glutamatergic Systems and Memory Mechanisms Underlying Opioid Addiction Jasper A. Heinsbroek, Taco J. De Vries and Jamie Peters

Mechanisms of Nicotine Addiction Marina R. Picciotto and Paul J. Kenny

Neural Substrates and Circuits of Drug Addiction Matthew W. Feltenstein, Ronald E. See and Rita A. Fuchs

The Role of the Central Amygdala in Alcohol Dependence Marisa Roberto, Dean Kirson and Sophia Khom

For additional articles in this collection, see http://perspectivesinmedicine.cshlp.org/cgi/collection/ 